\title{
Correlation and Nomenclature of Some Triassic and Jurassic Rocks in South-Central Wyoming
}

GEOLOGICAL SURVEY PROFESIONAL PAPER 594-D

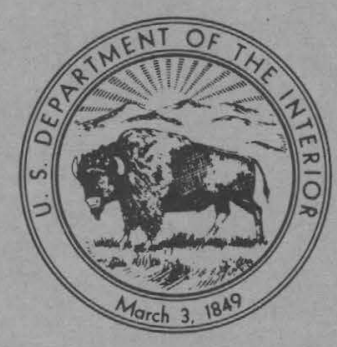





\section{Correlation and Nomenclature}

of Some Triassic and Jurassic

Rocks in South-Central

\section{Wyoming}

By GEORGE N. PIPIRINGOS

SHORTER CONTRIBUTIONS TO GENERAL GEOLOGY

GEOLOGICAL SURVEY PROFESSIONAL PAPER 594-D

$A$ revision of the correlation and

nomenclature of the upper part of the

Triassic System and of the marine part

of the Jurassic System in south-central

Wyoming

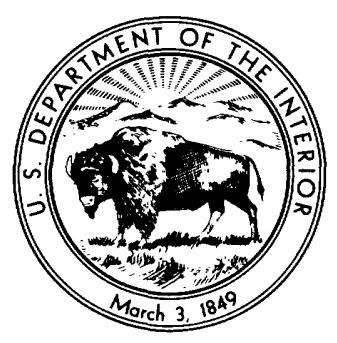

UNITED STATES GOVERNMENT PRINTING OFFICE, WASHINGTON : 1968 
UNITED STATES DEPARTMENT OF THE INTERIOR

STEWART L. UDALL, Secretary

GEOLOGIGAL SURVEY

William T. Pecora, Director

For sale by the Superintendent of Documents, U.S. Government Printing Office

Washington, D.C. 20402 - Price 30 cents (paper cover) 


\section{CONTENTS}

Abstract

Introduction.

History of nomenclature

Fieldwork

Triassic rocks

Jelm Formation and equivalent strata

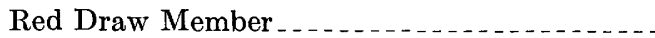

Sips Creek Member.

Popo Agie Formation.

Brynt Draw Member.

Lyons Valley Member.

Triassic(?) rocks

Nugget Sandstone.

Bell Springs Member.

\begin{tabular}{r|} 
Page \\
D1 \\
1 \\
2 \\
13 \\
13 \\
13 \\
13 \\
13 \\
15 \\
15 \\
15 \\
16 \\
16 \\
16
\end{tabular}

Triassic(?) and Jurassic(?) rocks . . Nugget Sandstone, upper part

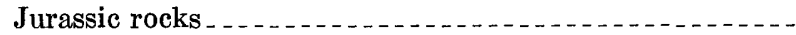

Gypsum Spring Formation......

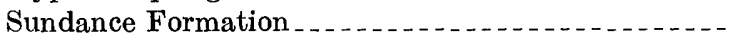

Canyon Springs Sandstone Member........ Massive sandstone unit.............

Flat-bedded sandstone unit . . . . . . . . .

Stockade Beaver Shale and Hulett Sandstone Members

Lak Member.

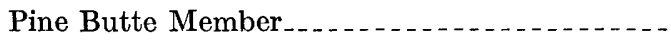

Redwater Shale Member. .................

Windy Hill Sandstone Member............

References cited

Page

D17

17

18

18

18

18

19

19

21

22

23

23

23

25

\section{ILLUSTRATIONS}

Figure 1. Index map

2. Restored section showing nomenclature and correlation of the Jelm Formation and overlying rocks to the middle of the Sundance Formation

3. Restored section showing nomenclature and correlation of the upper part of the Sundance Formation.... 4-8. Columnar sections showing correlation and nomenclature of Triassic and Jurassic rocks between:

4. Ferris Mountains, west, and Bell Springs...

5. Freezeout Mountains, southwest, and Flat Top anticline, west

6. Freezeout Mountains, east, and Red Mountain

7. Red Creek and Dallas anticline

8. Freezeout Mountains, east, and the Black Hills, S. Dak

9-23. Photographs:

9. Red Draw Member of the Jelm Formation

10. Sips Creek Member of the Jelm Formation

11. Brynt Draw and Lyons Valley Members of the Popo Agie Formation

12. Abrupt contact of the Popo Agie Formation and the Bell Springs Member of the Nugget Sandstone

13. Lyons Valley Member of the Popo Agie Formation near Rawlins, Wyo

14. Bell Springs Member of the Nugget Sandstone

15. Erosion surface between the Sips Creek Member of the Jelm Formation and the Canyon Springs Sandstone Member of the Sundance Formation at Freezeout Mountains, east . . . . . . . . . ...

16. Erosion surface between the Sips Creek Member of the Jelm Formation and the Canyon Springs Sandstone Member of the Sundance Formation near Freezeout Mountains, southwest........

17. Chert pebbles at the base of the Canyon Springs Sandstone Member of the Sundance Formation ...-

18. Chert pebbles stuck to uppermost surface of the Bell Springs Member of the Nugget Sandstone .-

19. Canyon Springs Sandstone Member of the Sundance Formation at Sheep Mountain

20. Pine Butte Member of the Sundance Formation and underlying units.

21. Pine Butte Member of the Sundance Formation and overlying units

22. Windy Hill Sandstone Member of the Sundance Formation

23. Bedding features typical of the Windy Hill Sandstone Member of the Sundance Formation

\section{TABLE}





\title{
GORRELATION AND NOMENGLATURE OF SOME TRIASSIC AND JURASSIG ROGKS IN SOUTH-GENTRAL WYOMING
}

\author{
By George N. Pipiringos
}

\begin{abstract}
Correlation and nomenclature of the Triassic and Jurassic rocks between the top of the Alcova Limestone and the base of the Morrison Formation in south-central Wyoming are revised as a result of recent stratigraphic work. The Chugwater is raised to group rank, and the Red Peak, Alcova, Jelm, Crow Mountain, and Popo Agie are designated as formations in it. The name Jelm Formation is used in southeastern Wyoming for rocks that separate the overlying Popo Agie Formation from the underlying Alcova Limestone. North of the Granite Mountains in the Wind River Basin, Crow Mountain Sandstone is the name applied to rocks equivalent to the Jelm. The Nugget Sandstone is divided and the lower part is designated the Bell Springs Member. Rocks of the Sundance Formation between the Lak and Redwater Shale Members are designated the Pine Butte Member. Rocks of marine origin, previously included in the base of the Morrison Formation in south-central Wyoming, are designated the Windy Hill Sandstone Member of the Sundance Formation.
\end{abstract}

\section{INTRODUCTION}

The stratigraphy of Upper Triassic and Middle and Upper Jurassic rocks lying between the Alcova Limestone and the Morrison Formation in central and southeastern Wyoming, and their equivalents in northeastern
Utah and northwestern Colorado, has been under investigation since 1958. The study has indicated that many of the currently accepted correlations of these rocks within the study area with the rocks of type sections in adjacent areas are erroneous, and that some nomenclature heretofore applied to these rocks needs revision. Some results of the continuing investigation by Pipiringos have been announced in yearly summaries of U.S. Geological Survey research $(1962,1963,1964$, 1965).

New nomenclature for south-central Wyoming is presented in this report and should be useful to those engaged in fieldwork in this and adjacent areas. The conclusions given here are based on the study of outcrops of Triassic and Jurassic rocks at about 150 localities in Wyoming, northwestern Colorado, and northeastern Utah. Correlations are illustrated by stratigraphic sections at 29 of these localities, which are mostly in a line extending from the vicinity of Lander, Fremont County, to the Freezeout Mountains north of Medicine Bow, Carbon County (fig. 1). The locations of these sections are shown in table 1.

TABLE 1.-Name and location of stratigraphic sections shown in figure 1

\begin{tabular}{|c|c|c|c|}
\hline \multirow{2}{*}{ Number } & \multirow{2}{*}{ Name } & \multicolumn{2}{|l|}{ Location } \\
\hline & & Section, township, range & Quadrangle \\
\hline $\begin{array}{r}5 \\
6 \\
7 \\
8 \\
9 \\
10 \\
11 \\
12 \\
14 \\
15 \\
18 \\
22 \\
28 \\
30 \\
31 \\
32 \\
33 \\
34 \\
35\end{array}$ & $\begin{array}{l}\text { Lander } \\
\text { Dallas anticline } \\
\text { Derby dome. } \\
\text { Johnson Ranch. } \\
\text { Sheep Mountain } \\
\text { Beaver Creek } \\
\text { Connant Creek } \\
\text { Gas Hills } \\
\text { Murphy Creek } \\
\text { Pine Mountain } \\
\text { Bessemer Mountain } \\
\text { Jones Ranch } \\
\text { Happy Spring } \\
\text { Green Mountain } \\
\text { Ferris Mountains, west } \\
\text { Ferris Mountains, east. } \\
\text { Hurt Creek. } \\
\text { Seminoe Mountain, east. } \\
\text { Sips Creek }\end{array}$ & 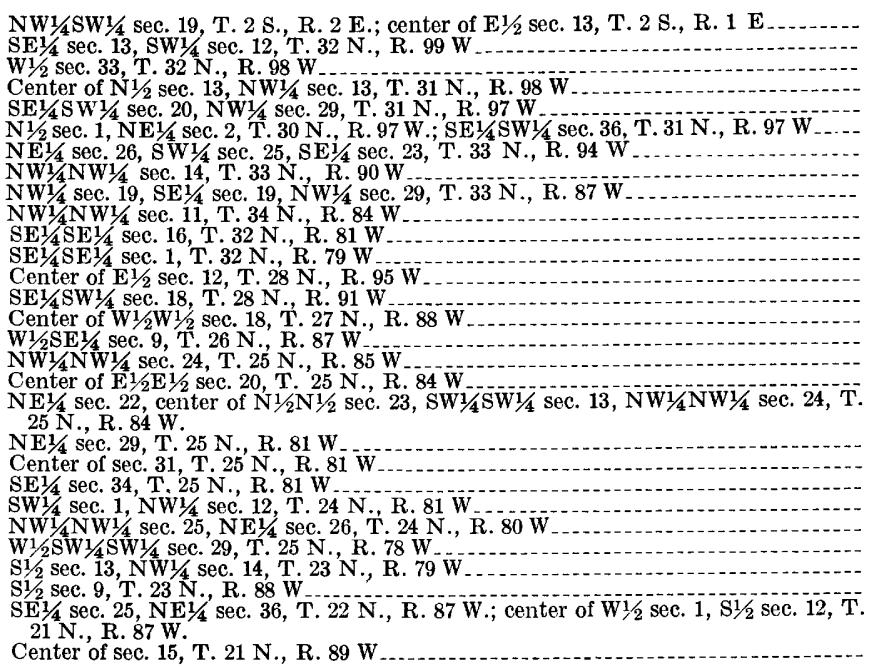 & $\begin{array}{l}\text { Lander, Lander NW. } \\
\text { Weiser Pass, Lander SE. } \\
\text { Weiser Pass. } \\
\text { Del Monte Ridge, Weiser Pass. } \\
\text { Del Monte Ridge. } \\
\text { Red Canyon, Schoettlin Mountain. } \\
\text { Blue Gulch. } \\
\text { Gas Hills. } \\
\text { Garfield Peak. } \\
\text { Square Top Butte. } \\
\text { Bessemer Mountain. } \\
\text { Brookhurst. } \\
\text { Soap Holes. } \\
\text { Split Rock NW. } \\
\text { Muddy Gap. } \\
\text { Ferris. } \\
\text { Seminoe Dam. } \\
\text { Seminoe Dam SW. } \\
\text { Seminoe Dam NE. } \\
\text { T E Ranch. } \\
\text { Do. } \\
\text { Difficulty. } \\
\text { Windy Hill. } \\
\text { T B Ranch. } \\
\text { Saddleback Hills, Como Ridge. } \\
\text { Rawlins Peak. } \\
\text { Rawlins. } \\
\text { Rawlins Peak. }\end{array}$ \\
\hline
\end{tabular}



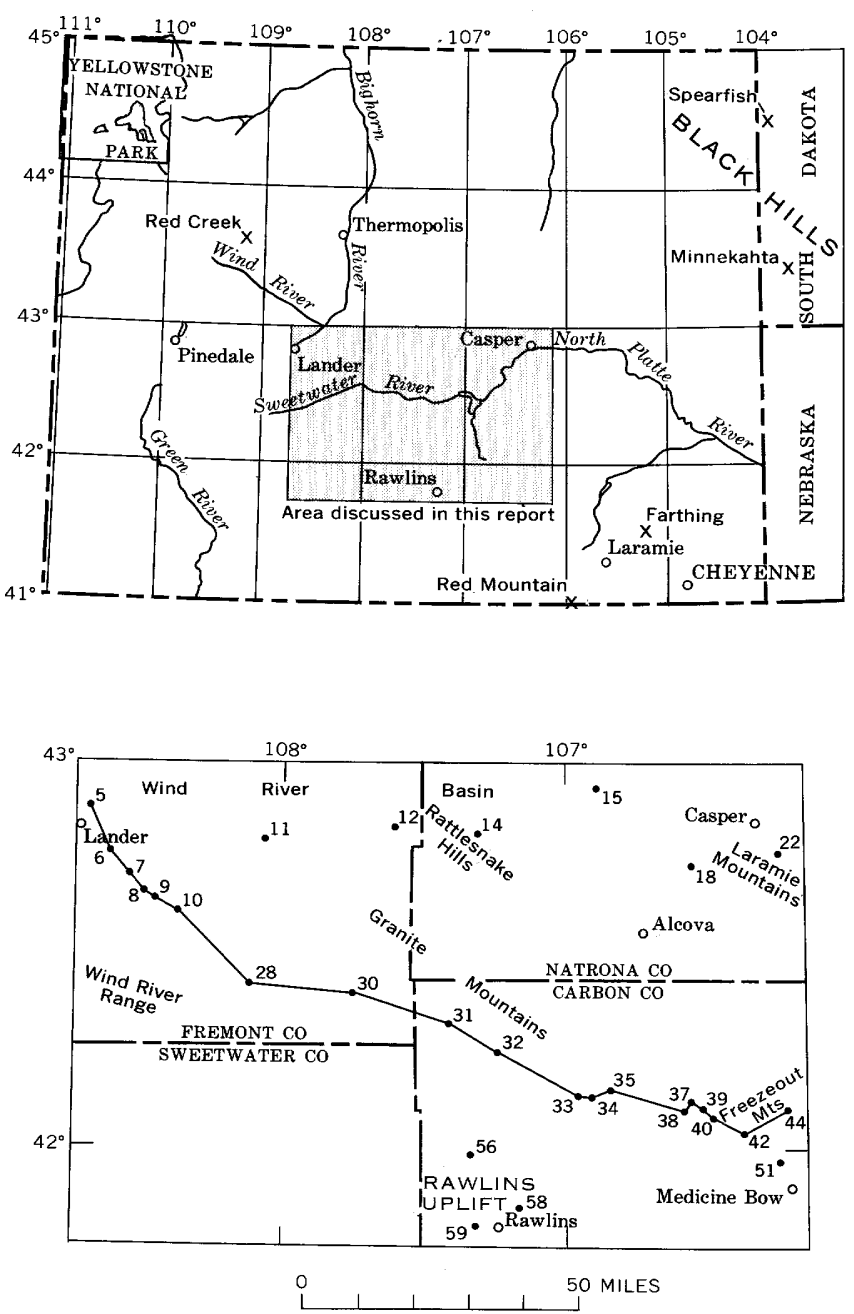

Figure 1.-Index map of south-central Wyoming showing line of sections, localities and areas referred to in this report. Localities are listed in table 1.

Triassic rocks discussed are in the Chugwater Group. The Nugget Sandstone of south-central Wyoming is tentatively assigned to the Triassic(?) and Jurassic(?). Jurassic rocks include the Gypsum Spring and Sundance Formations. Thicknesses, lithologies, facies changes, and other details of the stratigraphy are shown graphically in figures 2 through 8 . Figures 2 and 3 show correlations and nomenclature proposed here, whereas figures 4 through 8 illustrate the correlation of the rocks in south-central Wyoming with pertinent type sections, and the evolution of nomenclature for the sections shown.

Most of the rocks described herein are of marine or probable marine origin. They have an aggregate thickness of about 1,050 feet in the northwestern part of the area, and they thin to about 435 feet in the southeastern part. They comprise 7 formations and 12 members. The Red Peak, Alcova Limestone, Crow Mountain, and Popo Agie Members of the Chugwater Formation are here raised to formation rank, and the Chugwater is designated a group. The Jelm Formation replaces the Crow Mountain south and east of the Granite Mountains, where it separates the overlying Popo Agie Formation from the underlying Alcova Limestone. Furthermore, certain rocks of Triassic(?) age in the basal part of the Nugget Sandstone are designated the Bell Springs Member. A distinctive sequence of rocks that make up the basal part of the Redwater Shale Member of the Sundance Formation in the Black Hills and elsewhere is designated the Pine Butte Member of the Sundance Formation. And lastly, a thin unit of marine origin is removed from the base of the Morrison Formation of some previous writers and designated the Windy Hill Sandstone Member of the Sundance Formation.

\section{HISTORY OF NOMENCLATURE}

The Permian and Triassic "Red Beds" of early workers were named the Chugwater Formation (Darton, 1904) and included rocks from the top of the Tensleep Sandstone (Pennsylvanian) up to the base of the Sundance Formation (Late Jurassic). Subsequently, some rocks of Triassic age were removed from the upper part of the original Chugwater; and the Alcova Limestone Member where present, or the top of the Red Peak Member where the Alcova is absent, was designated the top of the Chugwater (Knight, 1917; Neely, 1937; Pipiringos, 1948a, b, 1953, 1957; Hubbell, 1954 ,1956). In this report area, the Chugwater is considered a group which comprises, from bottom to top, the Red Peak Formation, the Alcova Limestone, and the Jelm and Popo Agie Formations. North and west of the Granite Mountains, in the Wind River Basin, the name Crow Mountain Sandstone is used, instead of the name Jelm Formation.

The name Chugwater was extended into east-central Wyoming (Casper and vicinity) by Darton (1908), into south-central Wyoming (Rawlins and vicinity) by Lee, Stone, Gale, and others (1915), and into central Wyoming (Lander and vicinity) by Woodruff (1911).

In east-central Wyoming, the Alcova Limestone Member of the Chugwater was named for exposures near Alcova, about 29 miles southwest of Casper (Lee, 1927), The rocks above the Alcova and below the Sundance Formation were correlated with the Jelm Formation (Lee, 1927, p. 14 and pl. 1, locs. 23, 25). More recently, rocks, between the Alcova and the Sundance in the Alcova-Casper area have been referred to the Popo Agie Formation (Wroble, 1953) and to the Crow Mountain Sandstone Member of the Chugwater Formation (Love, 1958, fig. 1). Rocks that overlie the Alcova and underlie the Sundance in the Alcova-Casper area are assigned to the Jelm Formation in this report. 


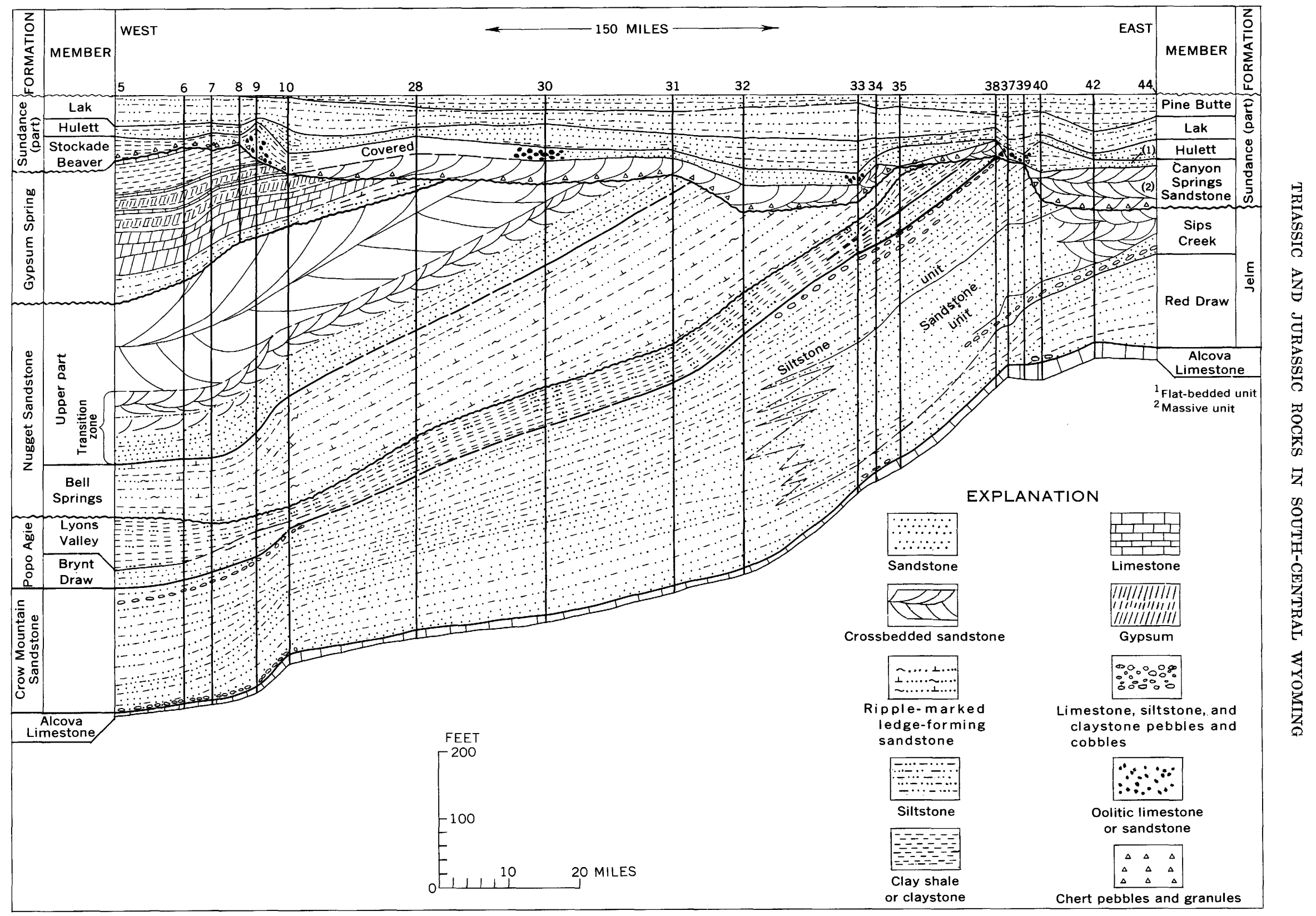

FrgURE 2.-Restored section showing nomenclature, correlation, dominant lithologies, and principal unconformities of the Jelm Formation and overlying rocks to the top of the Lak or of the Pine Butte Member of the Sundance Formation in south-central Wyoming. Line of section shown in figure 1. Unconformity shown by wavy line. 


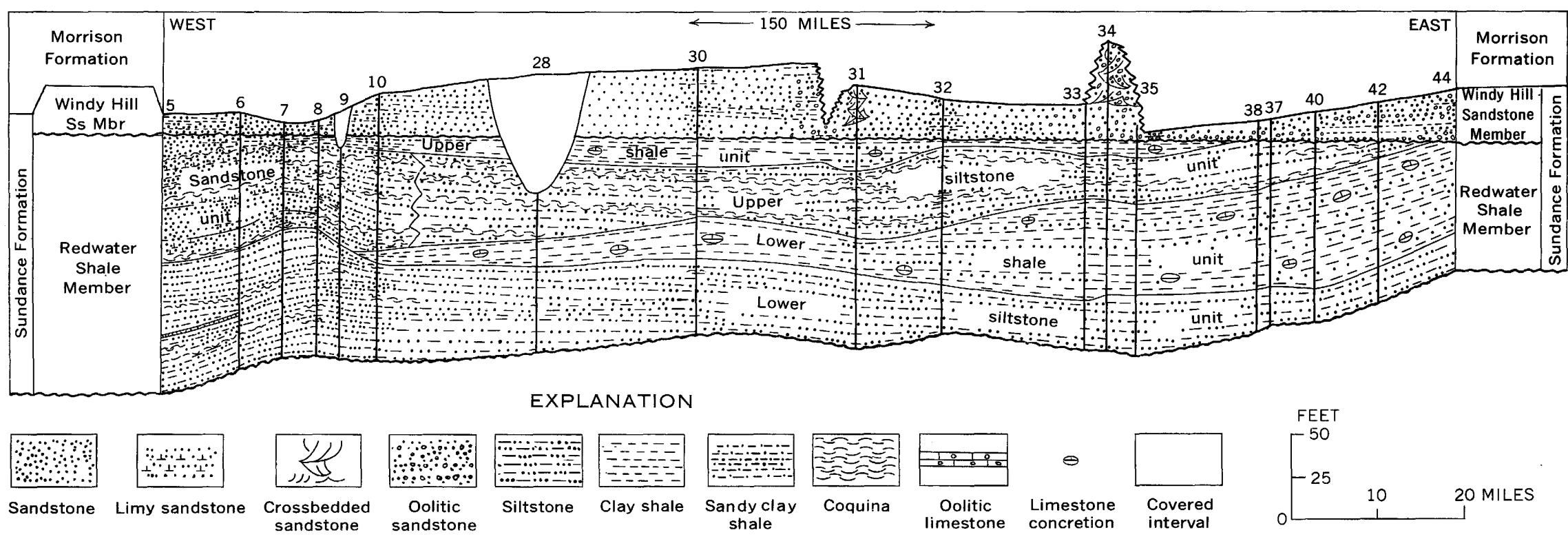

FIGURE 3.-Restored section showing nomenclature, correlation, and dominant lithologies of the Redwater Shale and Windy Hill Sandstone Members of the Sundance Formation in south-central Wyoming. Line of section shown in figure 1. Unconformity shown by wavy line. 


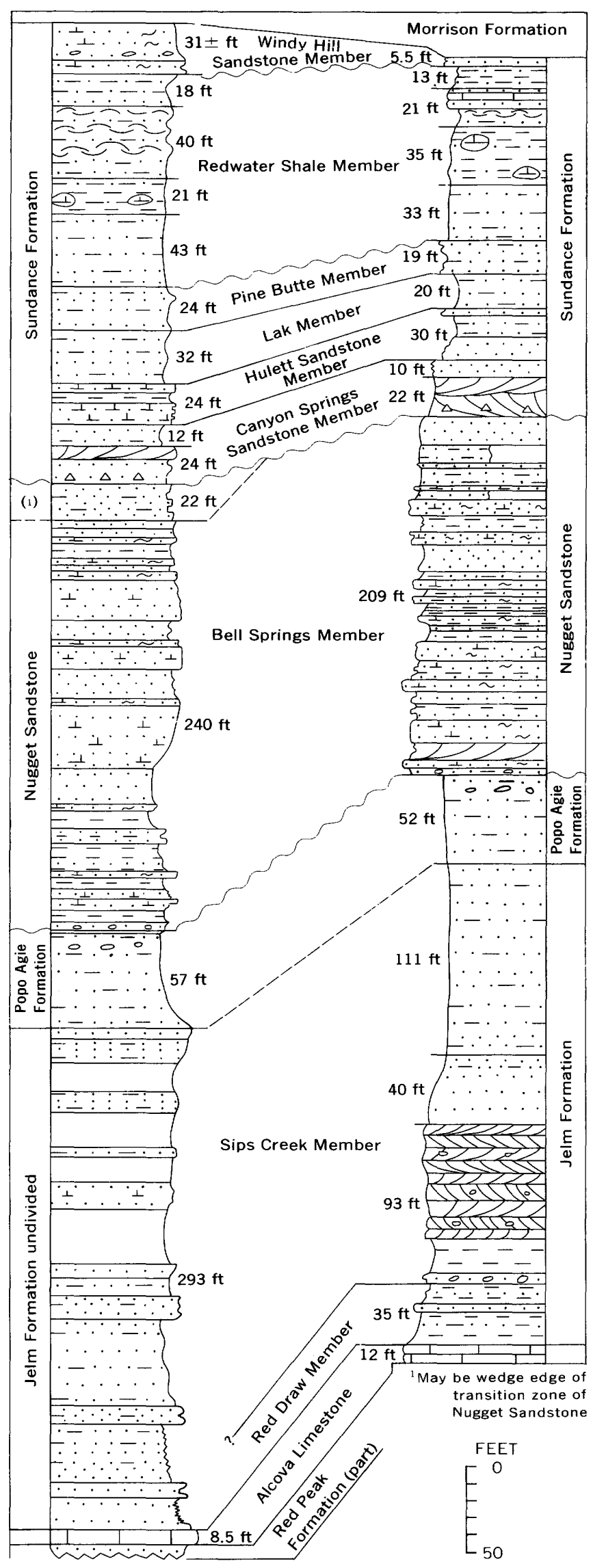

276-610 0-67-2
In south-central Wyoming the presence of the Chugwater and Sundance in the vicinity of Rawlins was noted by Lee, Stone, Gale, and others (1915, p. 14), but the contact between them was not described or illustrated. This contact was subsequently described at Bell Springs (loc. 56, figs. 1, 14), about 13 miles northwest of Rawlins, by Dobibin, Hoots, and Dane (1928, p. 179,180 and pl. 24B), who placed the ChugwaterSundance contact within the "Jelm (of this report) at the base of a "gray-white sandstone" 60 feet above the top of the Alcova. More recently, the names Jelm and Nugget Formations were used in the Rawlins uplift area (Hubbell, 1954; Dresser, 1959) for rocks above the Alcova and below the Sundance which here are assigned to the Jelm and Popo Agie Formations, and to the Bell ISprings Member of the Nugget Sandstone (fig. 4).

In central Wyoming, the first unit in the Chugwater to be differentiated was the Popo Agie Beds (Williston, 1904). The name Alcova Limestone Member of the Chugwater was introduced into the Lander area by Dobbin and Reeside (1927, p. 1235). They assigned the beds directly above the Alcova to the Jelm Formation and the Popo Agie Beds. The sandstone sequence above the Popo Agie Beds was correlated with the Nugget Sandstone of southwestern Wyoming and with the sandstone at the base of the Sundance Formation of the Black Hills (Canyon Springs Sandstone of present usage). The red shale beds and fossiliferous limestone beds (Gypsum Spring of present usage) above the Nugget were correlated by Dobbin and Reeside with beds within the lower part of the Sundance. Bauer (1934, table, p. 669) separated his Nugget(?) from the Sundance and from the underlying Jelm in the area between the south end of the Wind River Range and the Rattlesnake Hills (area extending from loc. 10 north and east to loc. 14, fig. 1). The Chugwater was divided into the Red Peak, Crow Mountain, Popo Agie, and Gypsum Spring Members by Love (1939, p. 44-45) in the Red Creek area. (ISee figs. 1, 7, this report.) The sandstone sequence above the Popo Agie and below the Gypsum Spring was named the Wyopo Formation of the Chugwater Group by Branson and Branson (1941), but it was correlated with the Nugget Sandstone by Love, Tourtelot, Johnson, Sharkey, Thompson, and Zapp (1945).

\footnotetext{
Figure 4.-Correlation and nomenclature of Triassic and Jurassic rocks between Ferris Mountains, west (loc. 31, fig. 1) (left side of figure), and Bell Springs (loc. 56, fig. 1) (right side of figure), south-central Wyoming. See figures 2 and 3 for explanation of lithologic symbols. Unconformity shown by wavy line.
} 


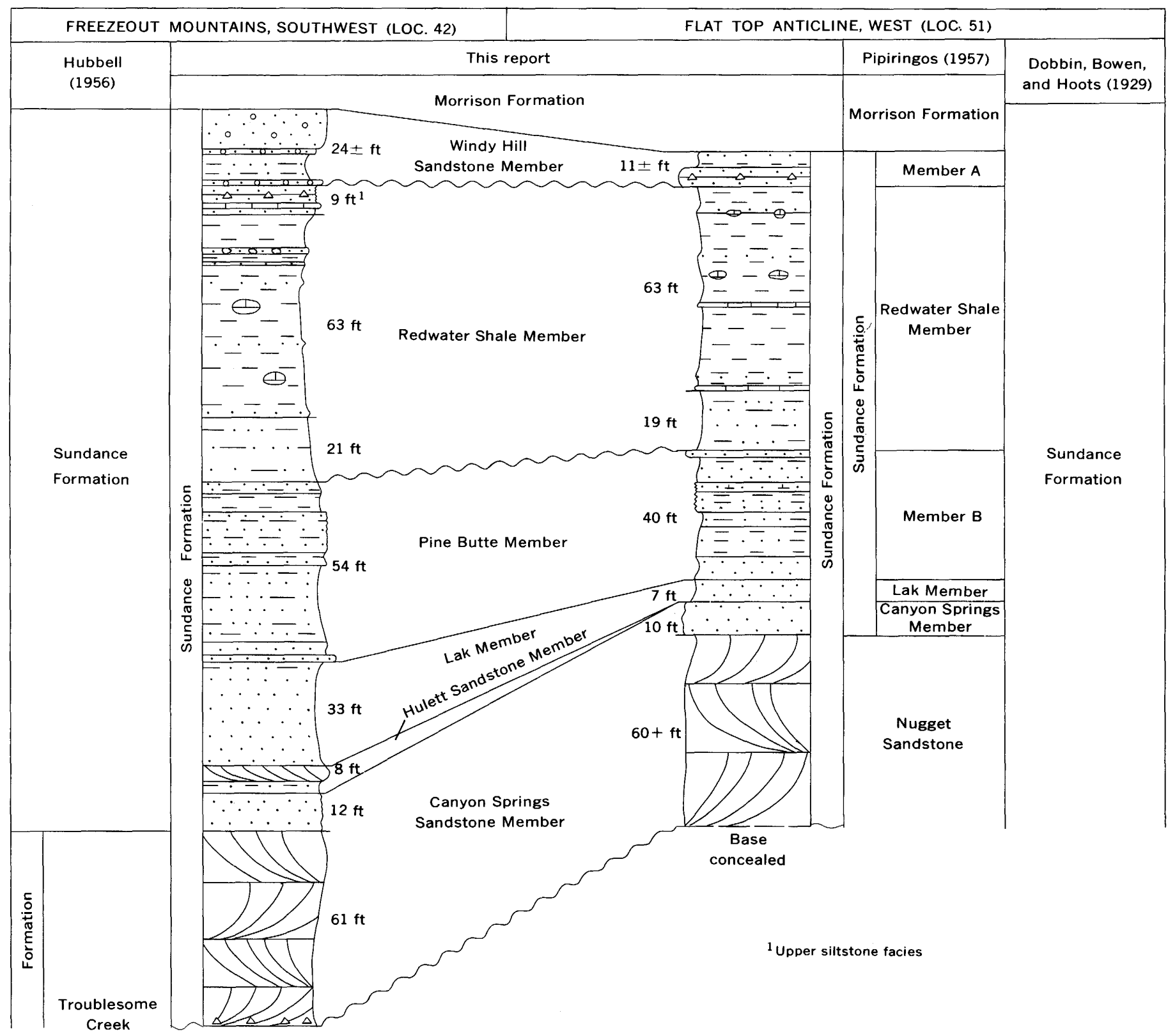




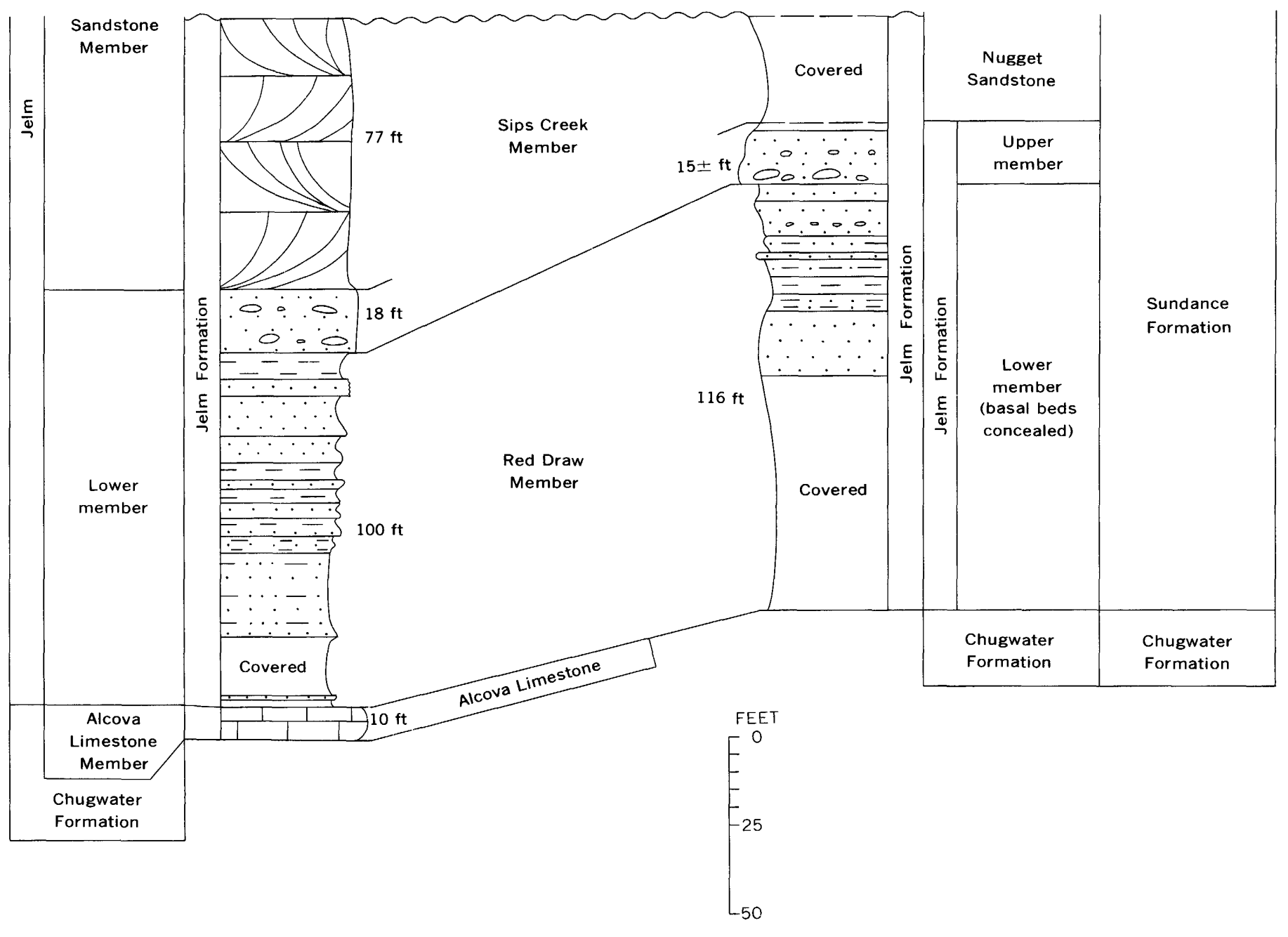

FIGURE 5.-Correlation and nomenclature of Triassic and Jurassic rocks between Freezeout Mountains, southwest (loc. 42, fig. 1), and Flat Top anticline, west (loc. 51, fig. 1), southeastern Wyoming. See figures 2 and 3 for explanation of lithologic symbols. Unconformity shown by wavy line. 


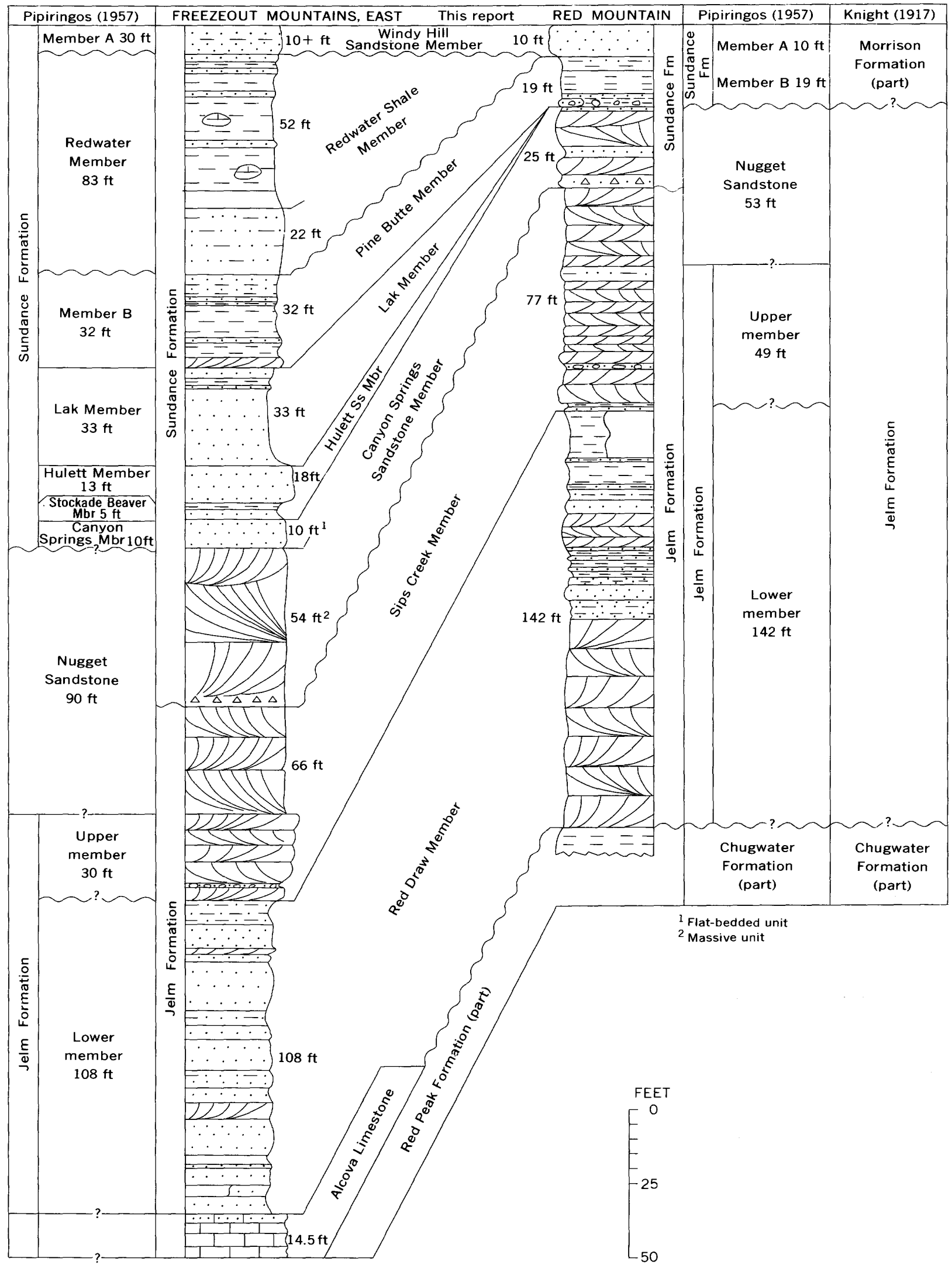

Figure 6.-Correlation and nomenclature of Triassic and Jurassic rocks between Freezeout Mountains, east (loc. 44, figs. 1-3), and Red Mountain (sec. 16, T. 12 N., R. 76 W., about 76 miles south of loc. 44), southeastern Wyoming. See figures 2 and 3 for explanation of lithologic symbols. Unconformity shown by wavy line. 
The names Red Peak, Alcova, Nugget, and Gypsum Spring have been used consistently in central Wyoming since 1945 (Imlay, 1945; Love, Johnson, and others, 1945; Love, Tourtelot, and others, 1945). The names Crow Mountain and Popo Agie have been used inconsistently, however, as indicated in figure 7 and later in the text. Stratigraphic subdivisions of the Triassic and Jurassic rocks proposed here for south-central Wyoming are shown in figures 2 and 3.

The marine "Jurassic rocks discussed in this report are in the Gypsum Spring and Sundance Formations.

The Sundance Formation was named from exposures in the Black Hills (Darton, 1899). The name was readily accepted and applied to marine Jurassic rocks throughout Wyoming except those along the west boundary. A sandstone sequence recognized by Darton at the base of the Sundance in the Black Hills was also recognized in the Alcova-Casper area, in southeastern Wyoming, and in the Rawlins area (Darton, 1908; Lee, 1927). In 1927, Lee noted the lithologic similarity of the basal sandstone sequence and the Nugget Sandstone of southwest Wyoming (Lee, 1927, p. 16). For many years thereafter, the basal sandstone sequence of the Sundance was correlated with the Nugget (Dobbin and Reeside, 1927; Dobbin and others, 1928; Reeside, 1929; Bartram, 1930, 1940; Wyoming Geol. Assoc., 1946, p. 14). Principally because of this long-held misconception, Imlay (1947, p. $229,234,235)$ was persuaded to tentatively assign the lower part of the basal sandstone sequence of Darton's Sundance in the southern part of the Black Hills to the Nugget(?) Sandstone. The remainder of Darton's Sundance above the Nugget(?) was divided by Imlay, in ascending order, into the Canyon Springs Sandstone, Stockade Beaver Shale, Hulett Sandstone, Lak, and Redwater Shale Members.

The Nugget(?) Sandstone of the Black Hills (Imlay, 1947, p. 234-236) is now known to be a facies of the lower part of the Canyon Springs at many places in the southern part of the Black Hills (Wilmarth and Smith, 1957; Dresser, 1959, p. 7-10; R. W. Imlay, oral commun., 1966; Donald Walcott, oral commun., 1966; fig. 8, this report).

The sandstone cliff shown in figure 15, at Freezeout Mountains, east (loc. 44, fig. 1), was considered an isolated outlier of the Nugget by Neely (1937, p. 747). Pipiringos (1948a, b, 1953, 1957) introduced Imlay's members of the Sundance into the Freezeout Mountains and noted in addition two new informal members, one above the Redwater Shale Member (Windy Hill Sandstone Member of this report) and one between the Lak and Redwater Shale Members (Pine Butte Member of this report). These new informal members and the Nug- get(?) of Neely (the lower part of the Sips Creek Member of the Jelm and the lower part of the Canyon Springs of this report) were traced by Pipiringos $(1948 \mathrm{a}, \mathrm{b}, 1953,1957)$ south to the vicinity of Red Mountain (fig. 1). Hubbell (1954) extended all the members of the Sundance, including those of Pipiringos (1948a, b, 1953, 1957), westward to Ferris Mountains, west (loc. 31, fig. 1), and to Bell Springs (loc. 56). He concluded that the Nugget(?) intertongued westward with red beds which in turn intertongued still farther west with the Nugget of central Wyoming. Inasmuch as Hubbell used the names Jelm and Popo Agie interchangeably in south-central Wyoming, this usage led to the belief that the Nugget intertongued with the Popo Agie.

This belief was in vogue from 1954. (Shaw and McGrew, 1954) until 1965, when Pipiringos (U.S. Geol. Survey, 1962) noted that the Nugget of the Wind River Basin did not intertongue with the Popo Agie, and High and Picard (1965) showed that an erosional surface of unconformity separated the Nugget of central Wyoming from the underlying rocks. Hubbell (1956) abandoned the name Nugget(?) in south-central Wyoming and substituted instead the name Troublesome Creek Sandstone Member of the Jelm (fig. 5). Love, Denson, and Botinelly (1949) were the first to question the correlation of the basal sandstone sequence of the Sundance Formation of east-central Wyoming with the Nugget of central Wyoming. H. W. Dresser (oral commun., 1958; Dresser, 1959) correctly included the upper part of the Nugget(?) and of the Troublesome Creek of the Freezeout Mountains in the Canyon Springs Sandstone Member of the Sundance Formation. He assigned the lower part of the cliffs shown in figures 9 and 15 of this report to the "Canyon Springs(?)-Jelm (?) sandstone." Dresser's questioning of the Canyon Springs-Jelm contact led me to the realization that the line of demarcation between two very similar lithologic units (figs. 9, 14, 15, 16, 17) is a widespread surface of erosion associated with chert pebbles everywhere, and that the pebbles are the principal diagnostic feature of the contact of the Sundance with underlying rocks in the area of this report.

All the members of the Sundance recognized by Imlay in the Black Hills and by Pipiringos, Hubbell, and Dresser in south-central Wyoming were also recognized in the Connant Creek-Rattlesnake Hills area (locs. 1114, fig. 1) and in the Alcova-Casper area (loc. 18, fig. 1) by Wroble (1953). Wroble's units were given letter designations (except for the Redwater Shale Member), and locally (loc. 14, fig. 1) one of his letter-designated units appears to be equivalent to the upper shale unit of the Redwater (fig. 3). 


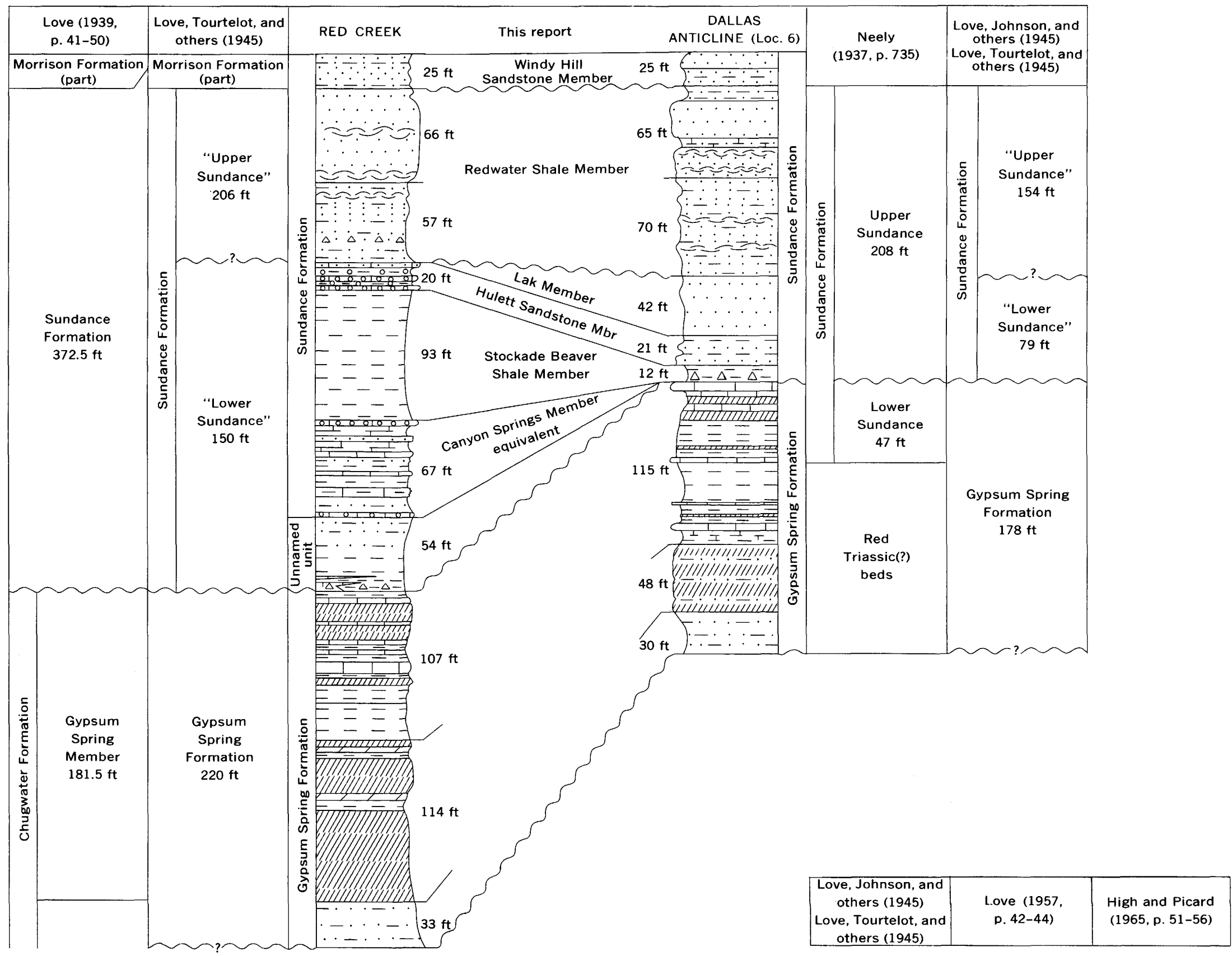




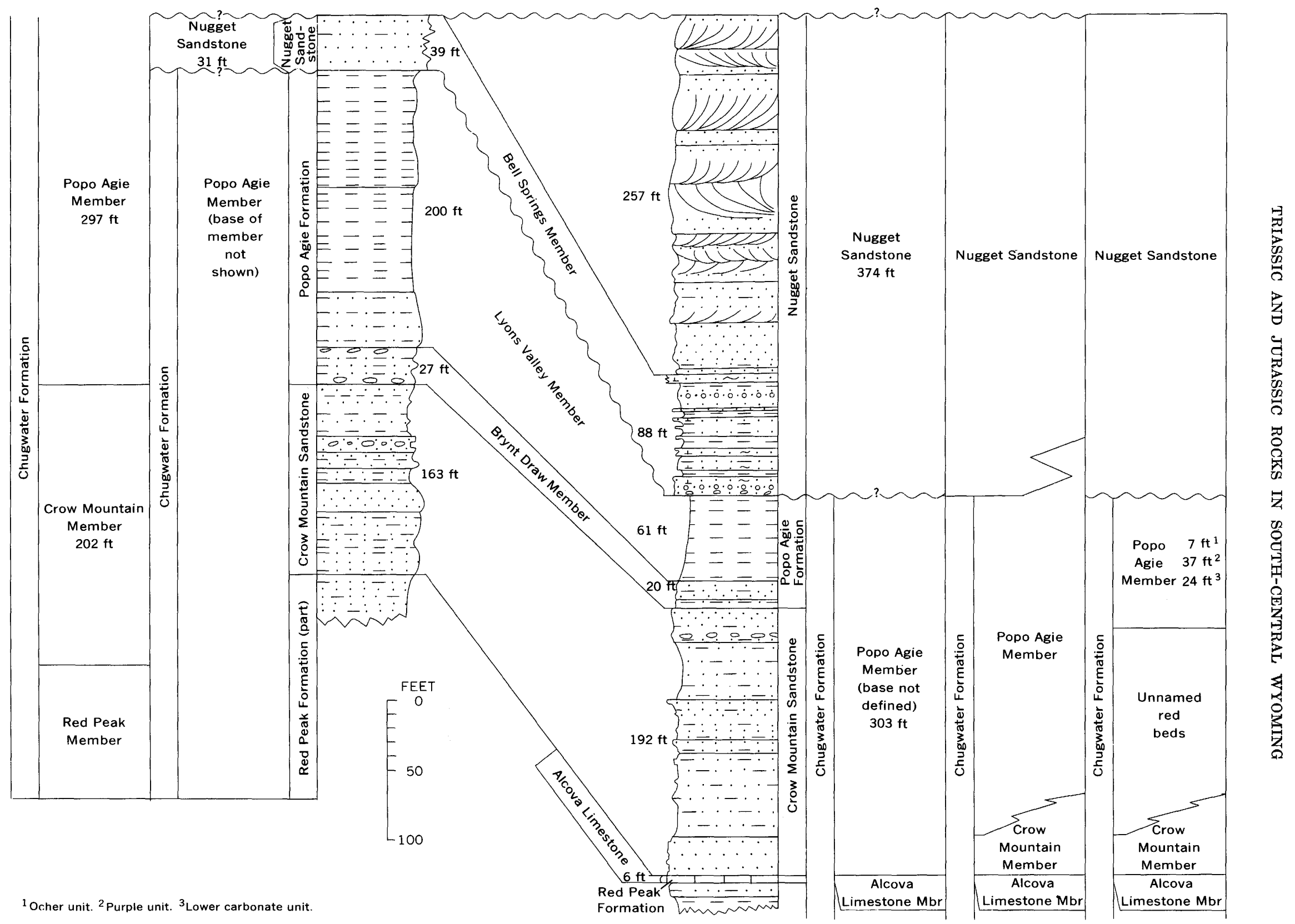

FrgURe 7.-Correlation and nomenclature of Triasic and Jurassic rocks between Red Creek (sec. 7, T. 6 N., R. 3 W., about 58 miles northwest of Lander), northwest Wyoming, and Dallas anticline (loc. 6, figs. 1-3), central Wyoming. See figures 2 and 3 for explanation of lithologic symbols. Wavy line indicates unconformity. 


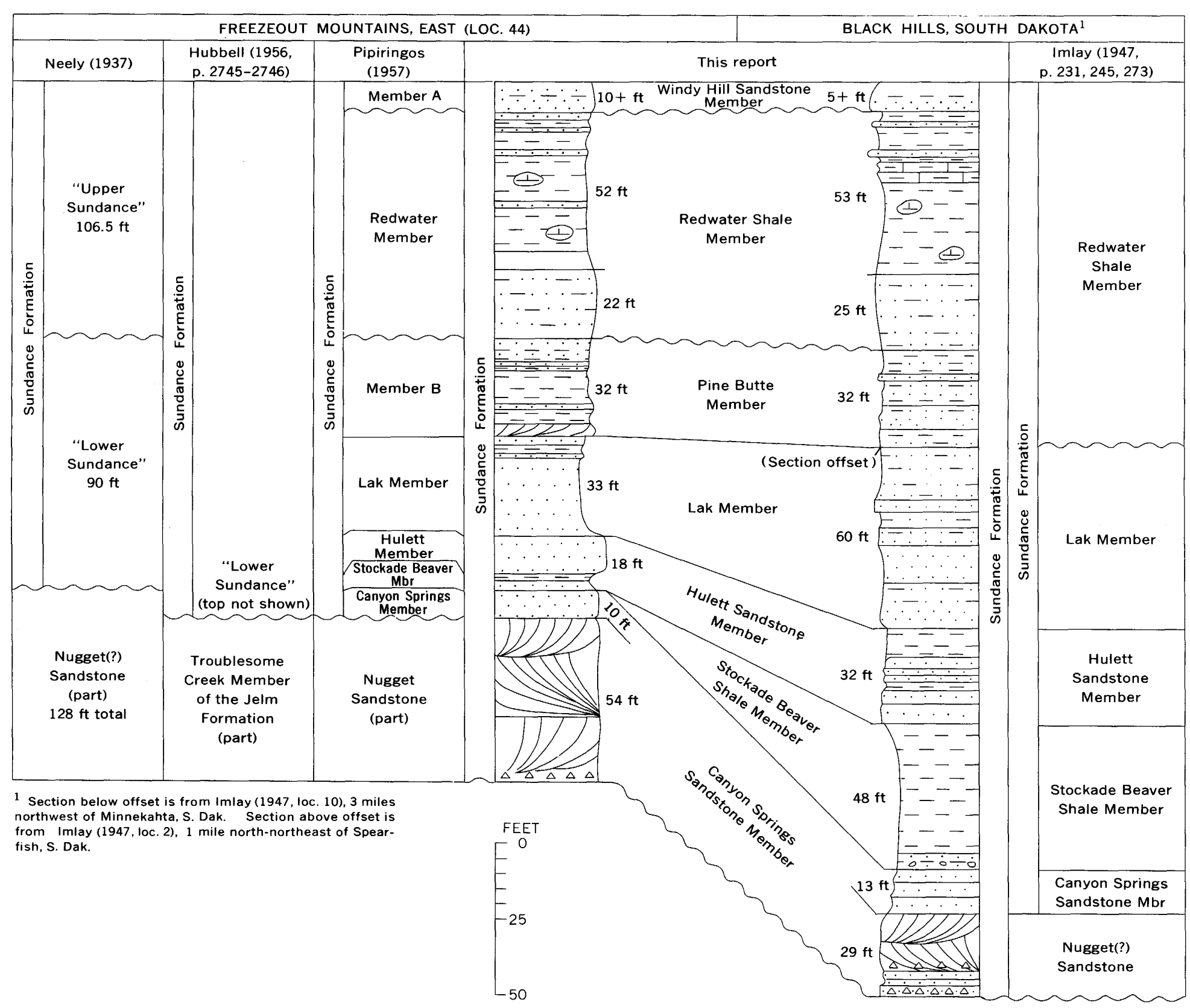

Figure 8.-Correlation and nomenclature of Triassic and Jurassic rocks between Freezeout Mountains, east (loc. 44, figs. 1-3), and the Black Hills, S. Dak. (140 miles northeast of the Freezeout Mountains). See figures 2 and 3 for explanation of lithologic symbols. Wavy line indicates unconformity. 
The names of the seven members of the Sundance recognized here are extended where the members are present throughout the area of this report.

\section{FIELDWORK}

Stratigraphic sections within the area of this report (fig. 1) were measured with the aid of the following persons during periods ranging from a few weeks to about 3 months in the years indicated: Robert $\mathrm{H}$. Erickson, 1947; Roland H. Shubert, 1958; Vicente P. Roque and James W. Mytton, 1960; and Robert G. Shean, 1961.

Stratigraphic sections outside the area of this report (fig. 1) were measured as follows. The Farthing section was measured with the assistance of Roland $\mathrm{H}$. Shubert in 1958; the Spearfish and Minnekahta sections in South Dakota) were measured by Ralph W. Imlay (1947, p. 245,273 ) and were modified by me for this report (fig. $8)$; the Red Creek and Red Mountain sections were measured by me.

\section{TRIASSIC ROCKS}

\section{JELM FORMATION AND EQUIVALENT STRATA}

The Jelm Formation was named for exposures near the east base of Jelm Mountain (Knight, 1917, p. 168). Lithologic units within the type Jelm and the relations of the Jelm to the overlying units are poorly exposed. Better exposures at Red Mountain were chosen as the type section (Pipiringos, 1957, p. 61). Red Mountain more properly should have been called the reference section of the Jelm Formation, and it is here so redesignated (fig. 6).

The Jelm Formation includes the Triassic rocks that lie above the Alcova Limestone and below the Popo Agie Formation. Rocks in this interval have been previously included in whole or in part in the Crow Mountain Sandstone Member of the Chugwater Formation (Love, 1939, 1957; fig. 7, this report), in the Popo Agie Member of the Chugwater Formation (Love, Tourtelot, and others, 1945; Love and others, 1947 ; Kummel, 1954, pl. 34; Love, 1957; Murphy and Richmond, 1965), and in unnamed units in the Chugwater Formation (Kummel, 1954, fig. 18; High and Picard, 1965, p. 51). The Crow Mountain Sandstone Member of the Chugwater Formation of Love (1939) is here designated the Crow Mountain Sandstone, a formation in the Chugwater Group.

The Jelm is about 360 feet thick in the southeastern part of the area (loc. 35 ) but is only about 25 feet thick near Casper (loc. 22); it averages about 225 feet in thickness in the area of this report. Northwest of locality 31, the Jelm consists mostly of reddish-brown siltstone interbedded with reddish-brown sandstone and $276-6100-67-3$ minor amounts of limestone pebble conglomerate. Southeast of locality 31 , the Jelm includes, in addition to the red beds, some distinctive greenish-white crossbedded sandstone and some conglomeratic sandstone, and it is divisible into two members.

The upper part of the Crow Mountain in the Lander area contains calcareous siltstone and silty limestone pebbles (figs. 2,7 ) very similar to those near the top of the Sips Creek Member of the Jelm at locality 35 (figs. $2,10)$. The upper part of the Jelm and Crow Mountain sequence in these two areas is probably correlative; but whether the thin sandstone sequence locally present at the base of the Crow Mountain in central Wyoming (fig. 11) corresponds to the sandstone sequence at the base of the Sips Creek (fig. 10) or to similar sandstone beds in the Red Draw Member (fig. 9) is uncertain, and the Crow Mountain in the Lander area is not subdivided.

Red Draw Member.-Red Draw is a new name here given to the lower part of the Jelm Formation in the southeastern part of the study area. The member is well exposed at locality 42, its type section (figs. 5, 9), and is named for Red Draw, about $21 / 2$ miles north. The member is about 100 feet thick at the type section, and consists of reddish-brown shale, siltstone, and sandstone interbedded with some greenish-gray siltstone that characteristically makes lime-cemented ripple-marked ledges. The Red Draw Member thins from the type section westward to about 35 feet at locality 56 (fig. 4 ) ; it can not be recognized to the northwest beyond this point. The member thickens slightly to the southeast from locality 42. It is about 140 feet thick at Red Mountain, reference section of the Jelm (fig. 6), where it was designated the lower member of the Jelm Formation and was described in detail by Pipiringos (1948a, 1953, 1957). The contact with the underlying Alcova Limestone is poorly exposed; at some localities, such as locality 44 , the contact appears to be gradational within a few inches, but a common and widespread occurrence of pebbles of Alcova in the basal few inches of the Jelm Formation and its correlative (locs. 5-10, 34, 40, fig. 2, and other localities north and northwest of Lander not shown in fig. 1) suggests that regionally the AlcovaJelm contact is a disconformity.

Sips Creek Member.-Sips Creek is a new name here given to the upper part of the Jelm Formation in the southeastern part of the study area. The member is well exposed near the Bennett Mountains at locality 35, its type section (fig. 10), and is named for Sips Creek, about 2 miles east. This member is as much as 315 feet thick at the type section but thins to zero in the northeastern part of the area. In the eastern part of the area, the contact with the underlying Red Draw Member is disconformable and is marked by a conglomerate. In the 


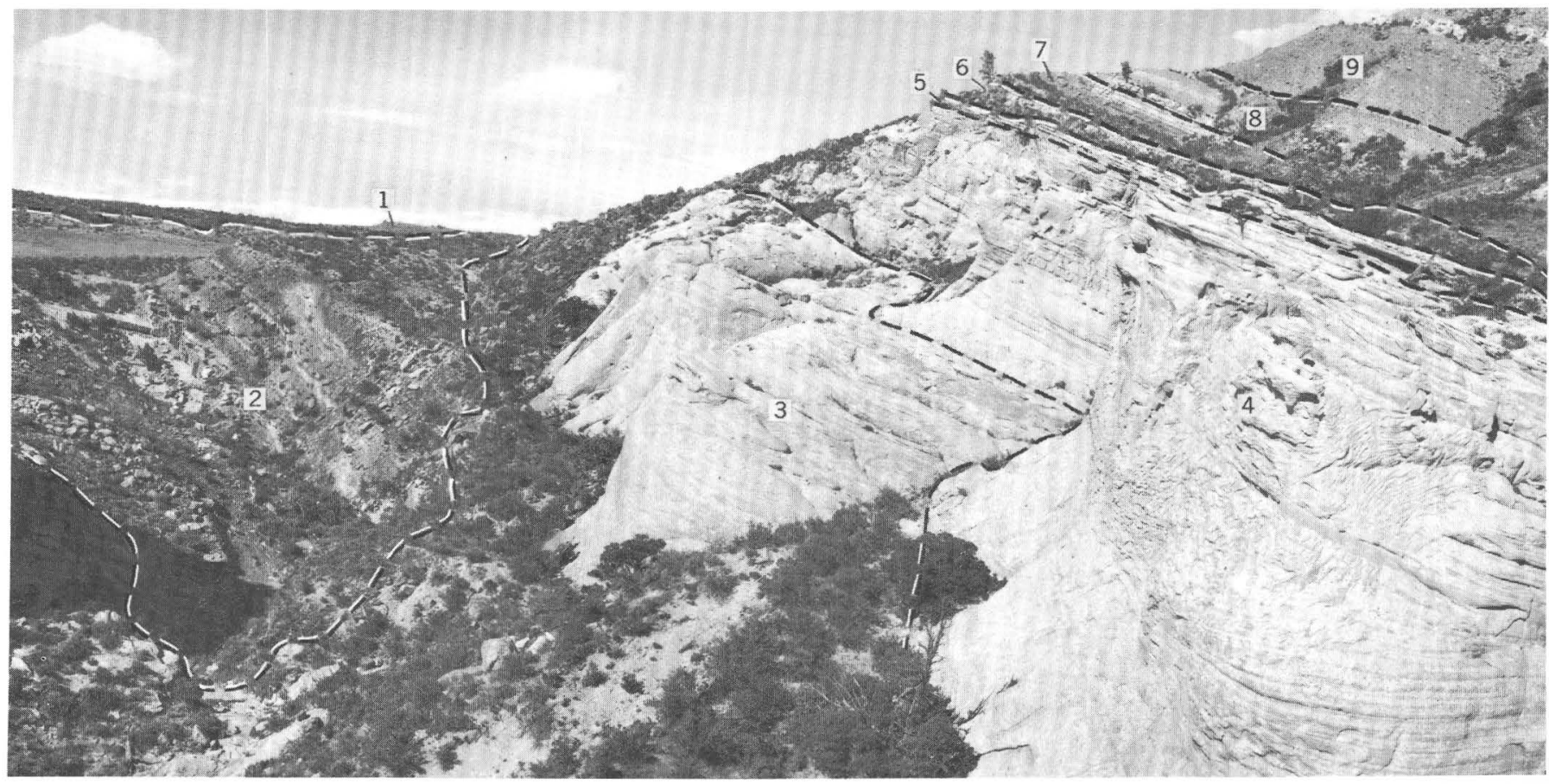

Frgure 9.-Red Draw Member of the Jelm Formation at the type section (loc. 42, fig. 1). (1) Alcova Limestone; (2) Red Draw and (3) Sips Creek Members of the Jelm Formation; (4) lower sandstone unit and (5) upper sandstone unit of the Canyon Springs Sandstone; (6) Hulett Sandstone, (7) Lak, (8) Pine Butte, and (9) Redwater Shale Members of the Sundance Formation.

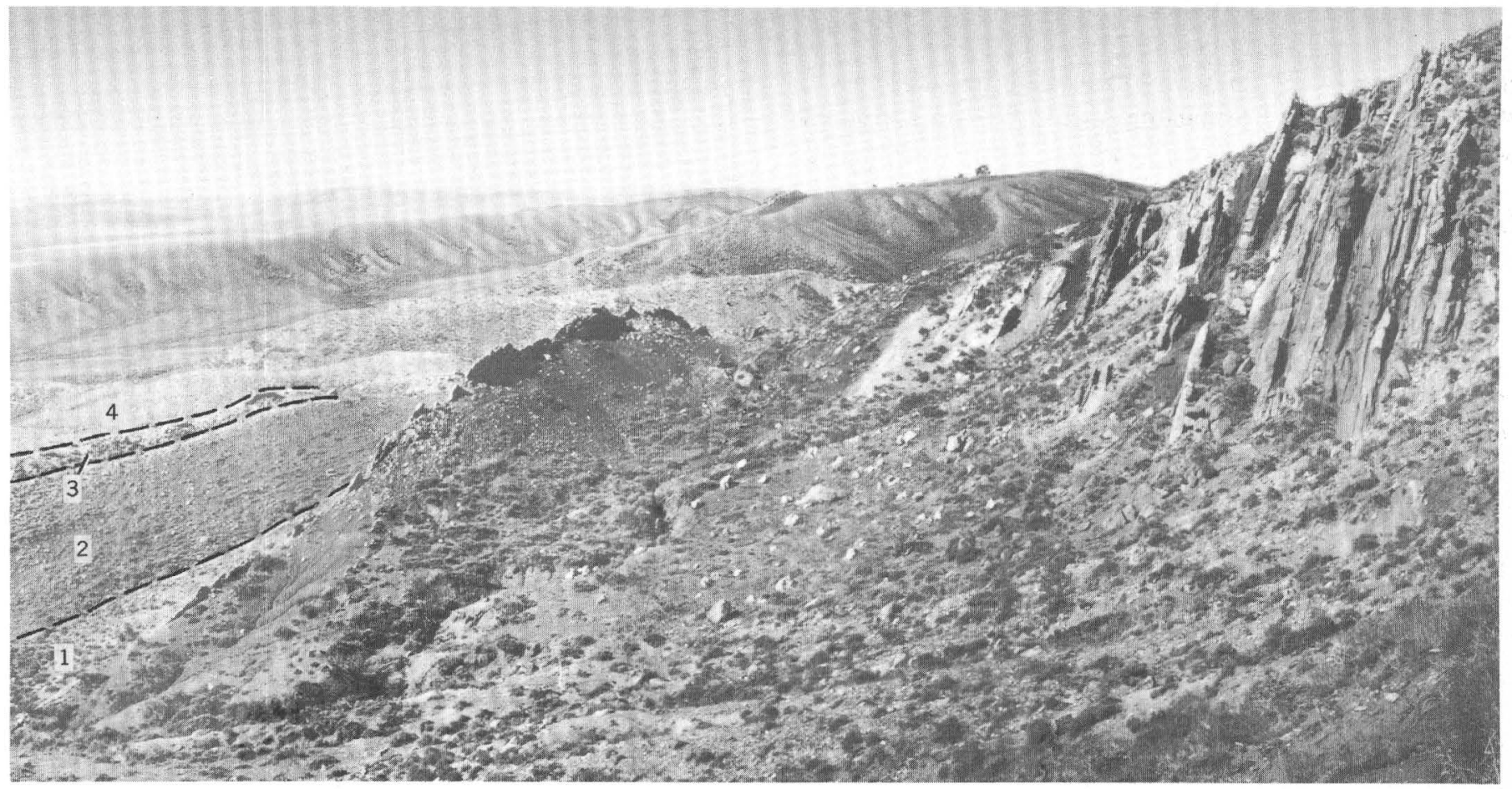

Figure 10.- Sips Creek Member of the Jelm Formation at the type section (loc. 35, fig. 1). (1) Sips Creek; (2) Popo Agie Formation; (3) Bell Springs Member of the Nugget Sandstone; (4) Sundance Formation. Base of Sips Creek Member concealed. Bed of calcareous siltstone pebbles firmly cemented by calcite near top of Sips Creek Member makes steep wall casting shadow near center of picture. 
western part of the area, the two members of the Jelm cannot be differentiated, and the nature of the contact is uncertain.

Southeast of locality 32 (fig. 2) the Sips Creek Member consists of sandstone in the lower part and siltstone in the upper part. The sandstone in the Freezeout Mountains is greenish white, massive, and crossbedded, and it forms steep cliffs. West of the Freezeout Mountains it is reddish brown and yellow and makes rounded ledges. In the Freezeout Mountains the basal 16-32 feet of the sandstone unit contains pebbles of siltstone, limestone, and shale and fragments of fossil wood and bone (figs. 5, 6). The sandstone matrix of these conglomeratic beds is greenish gray and contains abundant biotite, muscovite, and chlorite. The conglomeratic sandstone has been traced, with little change in thickness or lithology, from the Freezeout Mountains southward into the type Jelm (fig. 6; Pipiringos, 194.8a, b, 1953, 1957). Westward, the conglomerate grades into sandstone.

Siltstone in the upper part of the Sips Creek Member is reddish brown and forms smooth slopes. Beds of siltstone pebbles tightly cemented by white crystalline calcite form ledges generally in the uppermost 10-20 feet of the member.

\section{POPO AGIE FORMATION}

The name Popo Agie Formation is applied in this paper to rocks that overlie the Jelm Formation or equivalent strata and underlie the Bell Springs Member of the Nugget Sandstone. (See fig. 2, locs. 5-38.)

The Popo Agie is virtually a homogeneous lithogenetic unit. The rocks assigned to the formation are the same as those assigned to it by Keller (1952, p. 74-76) and by High and Picard (1965, p. 52). At the type locality (Keller, 1952, p. 76-77) the basal contact is not well exposed, although Keller's description of the Popo Agie is otherwise adequate. Love (1957, p. 42) included at the base of his Popo Agie about 60 feet of red beds that bear little lithologic resemblance to the Popo Agie of Keller and of this report. The Dallas anticline locality (loc. 6, figs. 1, 7, and 11) is here designated the reference section for the Popo Agie Formation because the formation is better exposed there, its relations to underlying and overlying rocks are clearer, and it is more accessible than at either the type locality of Keller or an alternate type locality proposed by Love (1957, p. 42). The Popo Agie is about 100 feet thick near Lander (loc. 5, fig. 2) but pinches out in the northeastern and southeastern parts of the area studied; northwest of Lander and south of the Rawlins uplift the formation thickens.

The lithologic change from the Jelm Formation to the Popo Agie Formation is from reddish-brown siltstone and sandstone to clayey siltstone and sandstone beds that are mottled pale red and gray, and analcimerich siltstone beds that are banded purple and ocher. Locally the contact of the Popo A Agie with the Jelm Formation appears to be gradational within about 1 foot. But at other places, including the Dallas anticline (loc. 6), Derby dome (loc. 7), and Rawlins, northeast (loc. 58), the contact is abrupt. Some of the analcime beds superficially resemble claystone (Keller, 1952, p. 74-77; High and Picard, 1965, p. 52). High and Picard (1965) have described in detail the petrography and mineralogy of the reference section of the Popo Agie Formation. Throughout its areal extent, the formation makes smooth slopes, in contrast to ledges and cliffs formed by the overlying Bell Springs Member and the ledgy slopes formed by the underlying Jelm Formation or Crow Mountain Sandstone (figs. 10, 11, 14).

The Popo Agie Formation is divisible into two members that are well exposed at the reference section and at localities northwest of Lander. The lower member is named here the Brynt Draw Member, and the upper member, the Lyons Valley Member. These names were derived from topographic features near the reference section of the Popo Agie (loc. 6), which also is designated the type section for both members. The two members can be distinguished at many places northwest of Lander, within the Lander area itself, and in the Rawlins area (loc. 58 and vicinity), but eastward from Beaver Creek (loc. 10) the members are not distinguishable.

Brynt Draw Member.-The Brynt Draw Member at its type section (loc. 6, figs. 1, 7, and 11) is about 20 feet thick and consists principally of pale-red to purplish-red silty claystone locally mottled-gray and grayish-yellow silty sandstone. The uppermost part of the member consists of dolomitic(?) siltstone containing lime-cemented siltstone pebbles. At other localities, shaly beds of grayish-purple siltstone that are mottled pale red and ocher, purplish-black iron oxide nodules, and aphanitic pinkish-gray limestone pebbles are common. In many places the member contains sandy, clayey siltstone beds that weather to fluted badland slopes having hard, gritty, rough surfaces that afford difficult footing even on gentle slopes.

Lyons Valley Member.-The Lyons Valley Member at the type section (loc. 6, figs. 11, 12) is about 60 feet thick and consists of purple and ocher siltstone, analcime-rich claystone, and analcimolite (Keller, 1952; High and Picard, 1965). This member is gradational downward into the Brynt Draw Member. The contact between the two at many places is marked topographically by a break in slope at the top of the Brynt Draw 


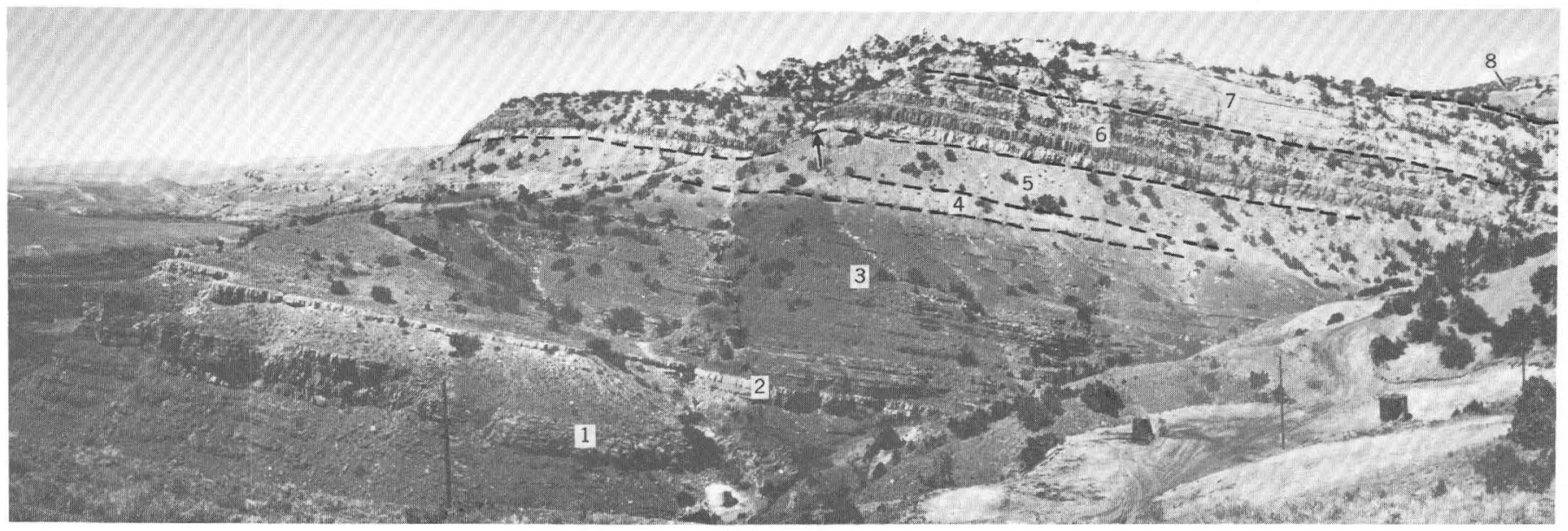

Figure 11.-Brynt Draw and Lyons Valley Members of the Popo Agie Formation at the type section (loc. 6, fig. 1). (1) Red Peak Formation; (2) Alcova Limestone; (3) Crow Mountain Sandstone; (4) Brynt Draw and (5) Lyons Valley Members of the Popo Agie Formation; (6) Bell Springs Member and (7) upper part of the Nugget Sandstone; and (8) Gypsum Spring Formation. Arrow points to Popo Agie-Bell Springs contact shown in figure 12.

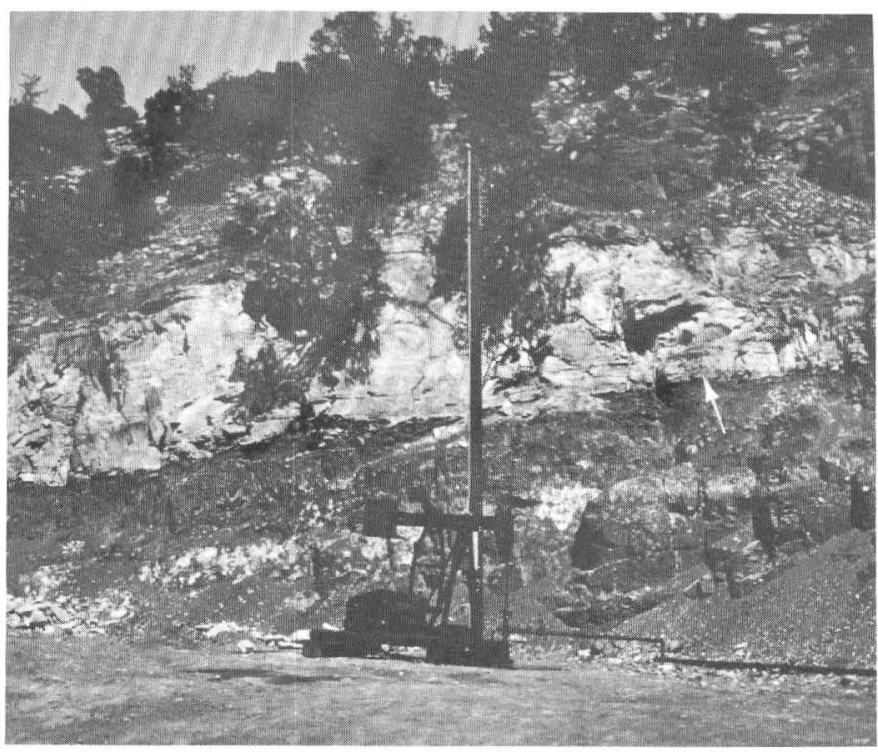

Figure 12.-Abrupt contact of the Popo Agie Formation and the Bell Springs Member of the Nugget Sandstone. Arrow points to contact.

separating hard, gritty, rough surfaces of the Brynt Draw from soft smooth slopes in the lower part of the Lyons Valley. Generally the lower part of the Lyons Valley is so deeply weathered that fresh samples are difficult to secure; this part of the member affords easy footing even where slopes are steep. By contrast, the upper part of the member weathers to small angular sharp-edged blocks that make even moderately steep slopes difficult to stand on.

The purple and ocher analcime-rich rocks of the Lyons Valley occur throughout much of the area of this report with little change in characteristics or appearance (figs. 12, 13). However, at Bell Springs (loc. 56, fig. 1; fig. 14) and at Ferris Mountains, west (loc. 31, fig. 1), rocks of this unusual lithology and appearance are inconspicuous, if present at all, and in the area $1 / 4$ mile to 11/2 miles south of Bell Springs, at Rawlins, west (loc. $59)$, and at more eastern localities $(32,33,34$, and 35 , fig. 1) occur then only as scattered ocher concretionary aggregates in the upper part of a sequence of pale-red siltstone. The lower part of the siltstone sequence is locally mottled purplish gray and pale purplish red much like the Brynt Draw Member, but the change from the mottled lower part to the ocher concretionary upper part is completely gradational. Both members of the Popo Agie are probably present but cannot be distinguished in the Bell Springs-Ferris Mountains area.

\section{TRIASSIC(?) ROCKS}

\section{NUGGET SANDSTONE}

\section{BELL SPRINGS MEMBER}

Bell Springs Member is a new name given here to a sequence of ripple-marked red and gray sandstone and red, green, and pale-purplish-red to pale-red siltstone and shale. The Bell Springs overlies the Popo Agie Formation throughout the area where the Bell Springs is present. It underlies the Sundance Formation in the Rowlins uplift at Ferris Mountains, east (loc. 32), and eastward to Sips Creek (loc. 35). East of locality 14 (fig. 1) and east of locality 35 (fig. 2), the member is truncated by the erosion surfaces at the base of the Sundance. Northwest of locality 32, the Bell Springs grades upward into the transition zone at the base of the upper part of the Nugget Sandstone. 


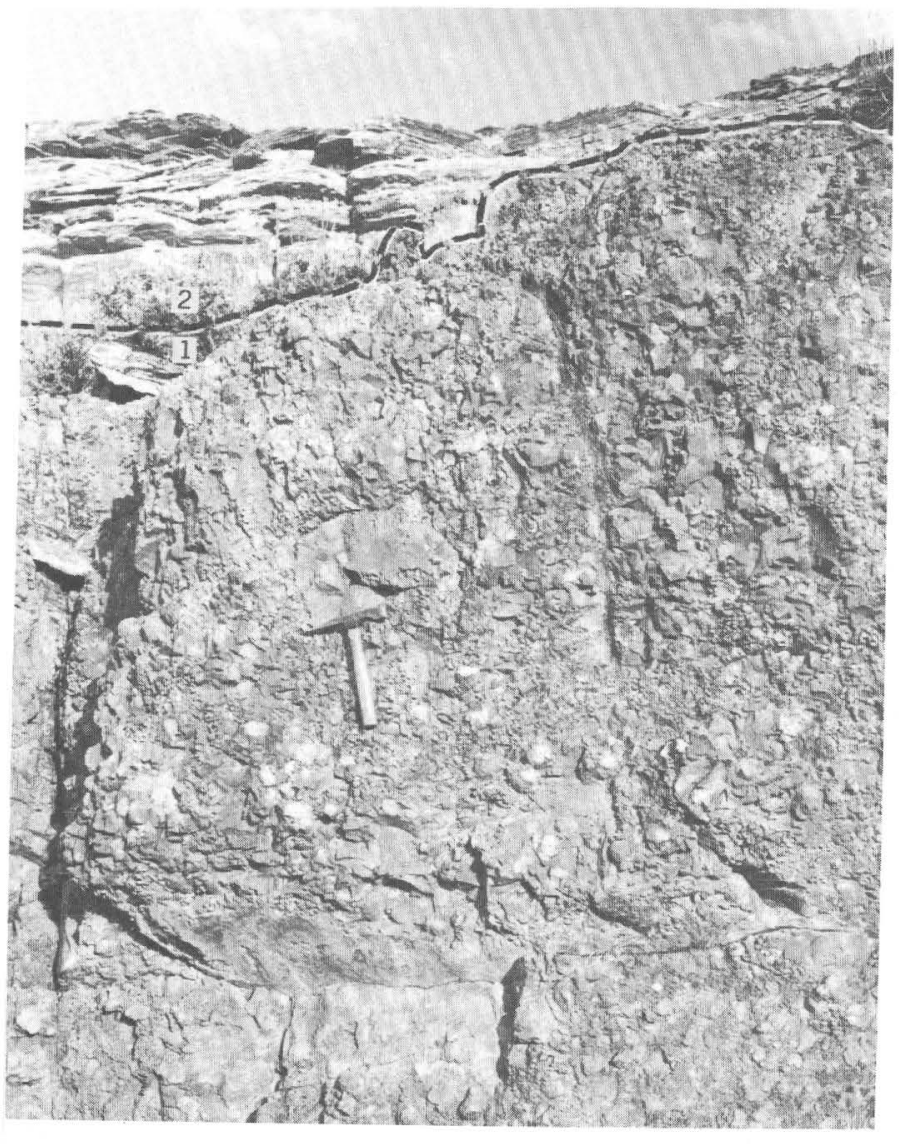

Figure 13.-Lyons Valley Member of the Popo Agie Formation at Rawlins, northeast (loc. 58, fig. 1). (1) Popo Agie Formation; (2) Bell Springs Member of Nugget Sandstone. The nodular weathered outcrop is typical of purple and ocher analcime-rich beds of the Popo Agie wherever they are well exposed.

The type section of the Bell Springs is in the $\mathrm{NW}^{1 / 4}$ $\mathrm{SE} 1 / 4$ sec. 9, T. $23 \mathrm{~N}$., R. $88 \mathrm{~W}$., about $11 / 2$ miles northeast of Bell Springs (loc. 56, figs. 1, 4, 14) in the Rawlins Peak quadrangle, Wyoming. The member is very well exposed at Rawlins, west, and Green Mountain (locs. 59 and 30, respectively, figs. 1, 3). The Bell Springs is about 210 feet thick at the type section. It thins from this point to about 170 feet at Rawlins, west (loc. 59, fig. 1), and about 60 feet at Rawlins, northeast (loc. 58, fig. 1). It is about 240 feet thick at Ferris Mountains, west (loc. 31, figs. 1 and 4), but the thickness there may have been increased somewhat by folding. In the Lander area (figs. 1, 2, and 7), the Bell Springs averages about 100 feet in thickness and represents the lower part of the Nugget Sandstone of Love, Tourtelot, Johnson, Sharkey, Thompson, and Zapp (1945).

The Bell Springs Member rests disconformably on the Popo Agie (figs. 2,12). At widely scattered localities, such as $6,31,35$, and 56 (fig. 1 ) the basal beds of the Bell Springs contain pebbles of ocher analcimic rocks derived from the Popo Agie and, at places, pebbles of chert and other rocks whose source is uncertain. Rarely, as at Rawlins, west (loc. 59, fig. 1), the basal bed is a calcite-cemented silty limestone-pebbble conglomerate similar to the conglomerate beds near the top of the Jelm Formation.

The Bell Springs contains some beds of very fine grained limy sandstone similar to the upper part of the Nugget Sandstone, but it can be distinguished readily from the upper part by the presence of pale-red to purplish-red shale beds and pale-blue-green firmly lime cemented siltstone beds generally less than 0.1 foot thick. Characteristic also of the Bell Springs, but not of the upper part of the Nugget, are calcareous firmly indurated sandstone beds, 1-4 feet thick, that are ripple laminated and weather to square-faced ledges.

Present stratigraphic studies indicate that the Bell Springs Member correlates with the upper part of the Chinle Formation of Kinney (1955) and of Poole and Stewart (1964) in northeastern Utah and northwestern Colorado. Therefore, the Bell Springs is of Triassic(?) age.

\section{TRIASSIC(?) AND JURASSIC(?) ROCKS}

\section{NUGGET SANDSTONE, UPPER PART}

The upper part of the Nugget Sandstone consists mostly of yellowish-white to pink sandstone and some reddish-brown silty sandstone. The upper part thins from a maximum thickness of 285 feet near Derby dome (loc. 7) to nothing east of localities 12 and 31 . It is absent near the Rawlins uplift, localities 56,58 , and 59 (fig. 1). The thinning is the result of truncation beneath an unconformity at the base of the overlying Gypsum Spring Formation, or where the Gypsum Spring is absent, beneath the Sundance Formation.

Where the upper part of the Nugget is thickest, its younger beds consist of sandstone that is thick bedded, friable, and conspicuously crossbedded. Its lower 90-150 feet is sandstone that is thinner bedded and less conspicuously crossbedded and locally contains ripple marks and mud cracks. The lower thinner bedded part grades downward into the Bell Springs Member; the basal contact is the top of the highest persistent sequence of pale-red shale, blue-green siltstone, and greenish-white resistant sandstone beds characteristic of the Bell Springs (fig. 11).

The gradational relation of the upper part of the Nugget with the underlying Triassic(?) Bell Springs Member and the unconformable relation of the Nugget to the overlying Jurassic Gypsum Spring Formation (figs. 2, 7) suggest that all the Nugget in central Wyo- 


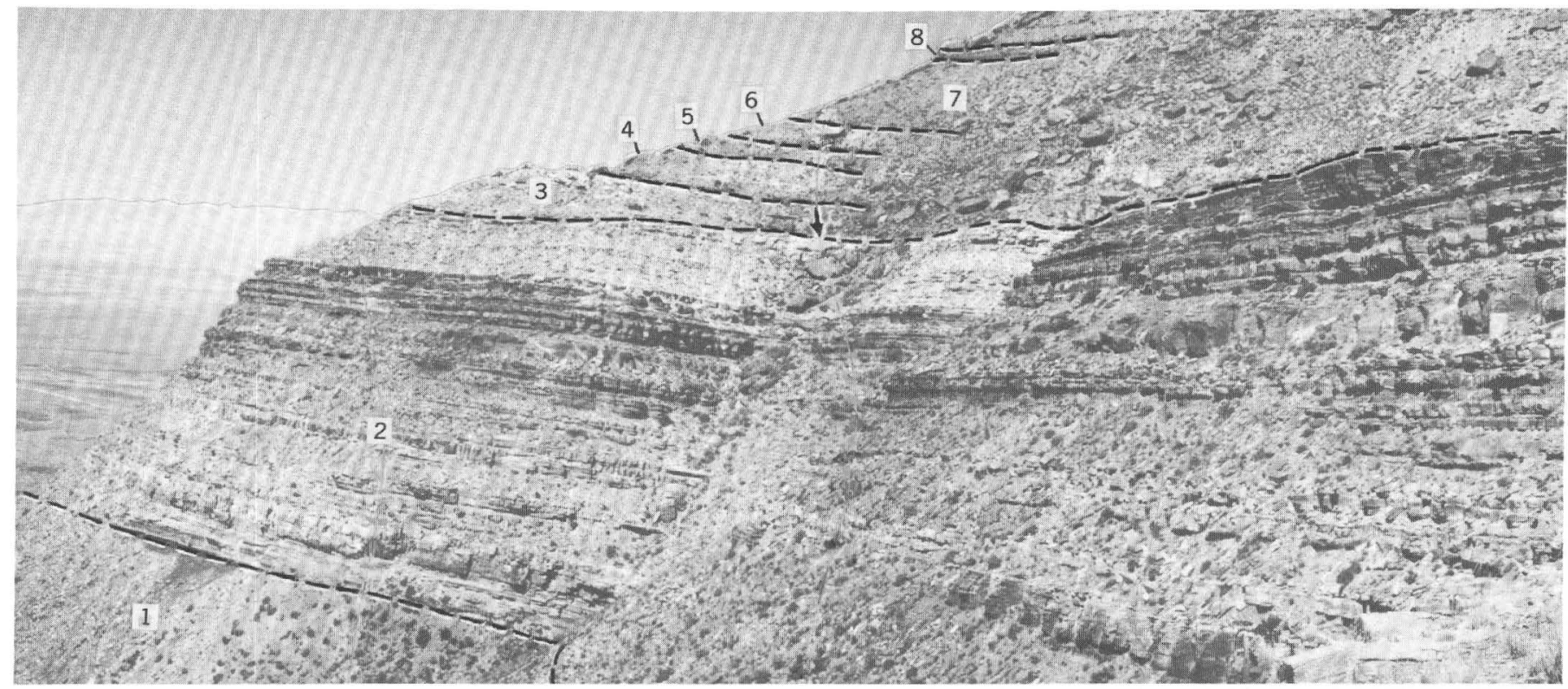

Figure 14.-Bell Springs Member of the Nugget Sandstone at the type section (loc. 56, fig. 1). View toward north; west end of Ferris Mountains in background. (1) Popo Agie Formation, base concealed; (2) Bell Springs Member; (3) Canyon Springs Sandstone (arrow points to good exposure of chert-pebble-studded uppermost surface of Bell Springs), (4) Hulett Sandstone, (5) Lak, (6) Pine Butte, (7) Redwater Shale, and (8) Windy Hill Sandstone Members of the Sundance Formation.

ming may be Triassic, rather than Jurassic as indicated by some previous writers (Imlay, 1945; Love, Tourtelot, and others, 1945). The upper part of the formation is here tentatively considered to be of Triassic(?) and Jurassic (?) age on this basis. A Triassic age for all the Nugget Sandstone was suggested by Love (1957) on the basis of presumed intertonguing of the lower part of his Nugget Sandstone (approximately the Bell Springs Member of this report) with the underlying Triassic Popo Agie; however, the work of Pipiringos (U.S. Geol. Survey, 1962) and High and Picard (1965) and the correlations shown in figure 2 indicate that the Nugget Sandstone of Love, Tourtelot, Johnson, Sharkey, Thompson, and Zapp (1945) and the Popo Agie do not intertongue and that the contact between them is a regional disconformity.

\section{JURASSIC ROCKS}

\section{GYPSUM SPRING FORMATION}

The Gypsum Spring Formation as described by Love, Tourtelot, Johnson, Sharkey, Thompson, and Zapp (1945) and Love, Tourtelot, Johnson, Thompson, Sharkey, and Zapp (1947) consists of reddish-brown siltstone in the lower part, gypsum in the middle part, and reddish-brown claystone and gray fossiliferous limestone in the upper part. The formation is 250 feet thick at the type section (Red Creek, fig. 7) and about 200 feet thick near Lander (loc. 5, figs. 1, 2), but it thins from this area eastward and is absent east of localities 11 and 28 (fig. 1). It is separated from the underlying Nugget Sandstone by a regional erosional unconformity (fig. 2). The three lithologic divisions of the formation recognized by Love, Tourtelot, Johnson, Sharkey, Thompson, and Zapp (1945) are readily distinguishable in the area described here.

\section{SUNDANCE FORMATION}

The Sundance Formation, which is entirely of marine origin, consists principally of sandstone, siltstone, and shale but contains lesser amounts of limestone. The formation is thickest in the north-central part of the area and thins westward, southward, and eastward. The thickness ranges from about 360 feet at locality 18 to about 195 feet at locality 38 , and from about 365 feet at locality 14 to about 200 feet at localities 7 and 8 (fig. 1 ). The average thickness is about 250 feet. The formation is separated from the underlying older rocks by a pronounced regional unconformity (fig. 2). The Sundance Formation is divided into seven members, two of which, the Pine Butte and Windy Hill Sandstone, are new.

\section{CANYON SPRINGS SANDSTONE MEMBER}

The name Canyon Springs Sandstone Member is used here as defined by Imlay (1947, p. 247-251). The Canyon Springs in the southern Black Hills consists of several kinds of rocks that grade into or abruptly inter- 
tongue with one another. These include maroon and gray shale, fossiliferous siltstone and thin-bedded sandstone, massive sandstone, crossbedded sandstone, and locally fossiliferous flat-bedded ripple-marked oolitic sandstone. In contrast, the Canyon Springs of south-central Wyoming consists of but two of the several lithotypes present in the Black Hills : a lower, cliff-forming, crossbedded, and (or) massive sandstone unit and an upper ledge-forming flat-bedded ripple-marked oolitic sandstone unit that is locally fossiliferous. These two units are continuous throughout much of south-central and southeastern Wyoming, but they cannot be distinguished in the northern part of the report area, or in outcrops south of the Rawlins uplift, and they are absent from the northwestern part of the area studies. The Canyon Springs averages about 43 feet in thickness.

In the northern part of this report area, the entire Canyon Springs Sandstone Member is laterally equivalent to the lower part of the Stockade Beaver Shale Member. Lateral gradation is demonstrated within half a mile northwest from locality 14 (fig. 1), as approximately 55 feet of shale assigned to the Stockade Beaver and 65 feet of underlying oolitic sandstone assigned to the Canyon Springs pass laterally into an interval of the same thickness consisting entirely of shale. Lateral gradation of the two members occurs also in the Black Hills of Wyoming and South Dakota (Imlay, 1947, p. 239 ; Mapel and Bergendahl, 1956, p. 87, fig. 2).

\section{MASSIVE SANDSTONE UNIT}

The massive sandstone unit constitutes the upper part of the Troublesome Creek Member of the Jelm of Hubbell (1956, p. 2745 , beds 11 and 12 ; figs. 5 and 8 of this report) and is the same as the Nugget(?) of Imlay (1947, p. 234-235) in the Black Hills in northeastern Wyoming, the upper part of the Nugget of Pipiringos (1957) in the Freezeout Mountains (figs. 6, 15), and the lower part of the Canyon Springs Sandstone Member of the Sundance Formation of Dresser (1959).

The unit is well exposed in the southwestern part of the Freezeout Mountains at locality 42 (figs. 5, 9), where it is about 60 feet thick and consists of cliff-forming yellowish-white sandstone which is crossbedded on a large scale. At a few places, as at exposures about 1 mile southeast of Alcova, Wyo., the unit is oolitic, but at most places ooliths are inconspicuous or absent. The massive sandstone unit is absent from the northwestern part of the area (figs. 1 and 2); it averages about 35 feet in thickness where present elsewhere.

South of the Rawlins uplift, the lower, crossbedded and massive sandstone unit thickens at the expense of the overlying flat-bedded unit so that locally the entire Canyon Springs consists of crossbedded and massive sandstone.
At the base of the massive sandstone unit there are polished and pitted gray, black, and orange chert pebbles. These are generally concentrated in a zone an inch or two thick, but in places they occur throughout the lower 1 foot. The pebbles lie on an erosion surface at the base of the lower unit. Wherever the lower unit overlies the Jelm (figs. 9, 15, 16), the Bell Springs (figs. 14, 17, 18), or the upper part of the Nugget (loc. 30, fig. 2), the contact between the Canyon Springs and the underlying. unit would be difficult or impossible to ascertain were it not for the chert pebbles. Where the massive or crossbedded lower part of the Canyon Springs is absent, the chert pebbles occur at the base of the flat-bedded upper part of the Canyon Springs Sandstone Member of the Sundance (loc. 9, fig. 19), or, where the Canyon Springs is entirely absent, at the base of the Stockade Beaver Shale Member of the Sundance (locs. 5-8, 10; fig. 2).

The unconformity and the associated chert pebbles are present throughout the study area. The maximum relief of the erosion surface noted was 54 feet between localities 31 and 32 (figs. 1, 2). The erosion was of Middle Jurassic age. Similar chert pebbles mark this unconformity from the Black Hills of Wyoming and South Dakota southwestward for about 700 miles to near Zuni, N. Mex., and from Buckhorn Wash of the San Rafael Swell, Utah, eastward for about 300 miles to the vicinity of Boulder, Colo. Additional details of the distribution and stratigraphic relations of this unconformity were given in an earlier summary of investigations by Pipiringos (U.S. Geol. Survey, 1965).

\section{FLAT-BEDDED SANDSTONE UNIT}

The flat-bedded sandstone unit is represented in the Black Hills of Wyoming and South Dakota by the Canyon Springs of Imlay (1947, stratigraphic section 10, p. 228,273 ; fig. 8 of this report), and in other parts of Wyoming by the Canyon Springs of Pipiringos (1957) and by the upper part of the Canyon Springs of Dresser (1959).

The flat-bedded sandstone unit overlies the massive sandstone unit, and it is overlain by the Stockade Beaver Shale Member or the Hulett Sandstone Member (fig. 2). Rocks composing the flat-bedded sandstone unit are mostly fine-grained light-gray sandstone that is the same color as the massive unit but differs from it by being coarser grained, flat bedded, ripple marked, ledge forming, fossiliferous, and more abundantly oolitic. The thickness of the unit ranges from 0 to 26 feet (loc. 56 ) and averages about 14 feet.

The flat-bedded sandstone unit is most abundantly oolitic and firmly lime cemented in the northwestern part of the study area (fig. 2, loc. 30). At Sheep Mountain, in its westernmost exposure (loc. 9, figs. 1, 19), the unit is about 55 feet thick and rests directly on the Gyp- 

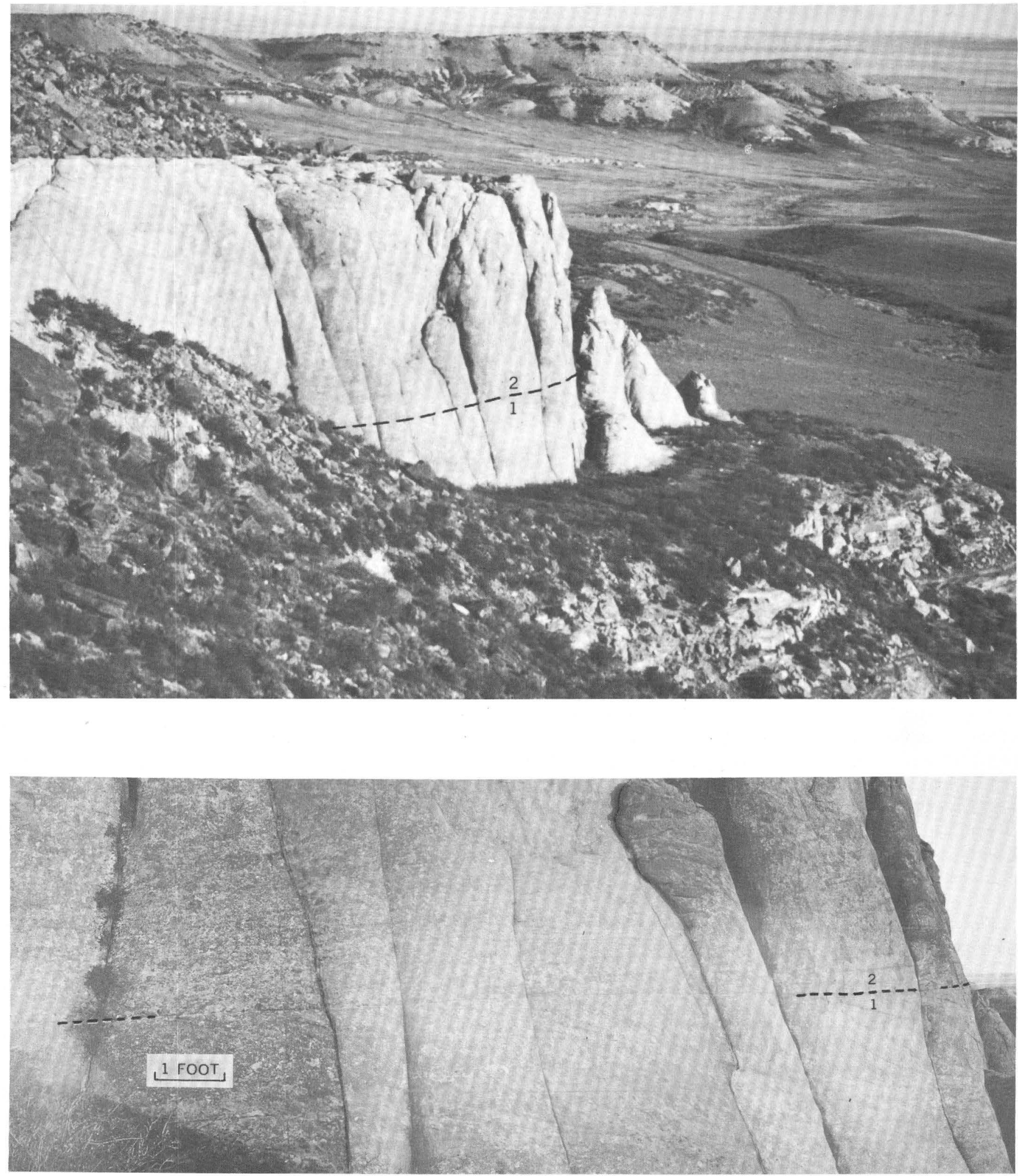

Fraure 15.-Erosion surface between the Sips Creek Member of the Jelm Formation (1) and the Canyon Springs Sandstone Member of the Sundance Formation (2) at Freezeout Mountains, east (loc. 44, fig. 1). Upper photograph is distant view; conglomeratic sandstone at base of Sips Creek Member makes ledge at lower right. Lower photograph is near view of contact (dashed line) shown in upper view; trace of the erosion surface is studded with scattered small chert pebbles. 


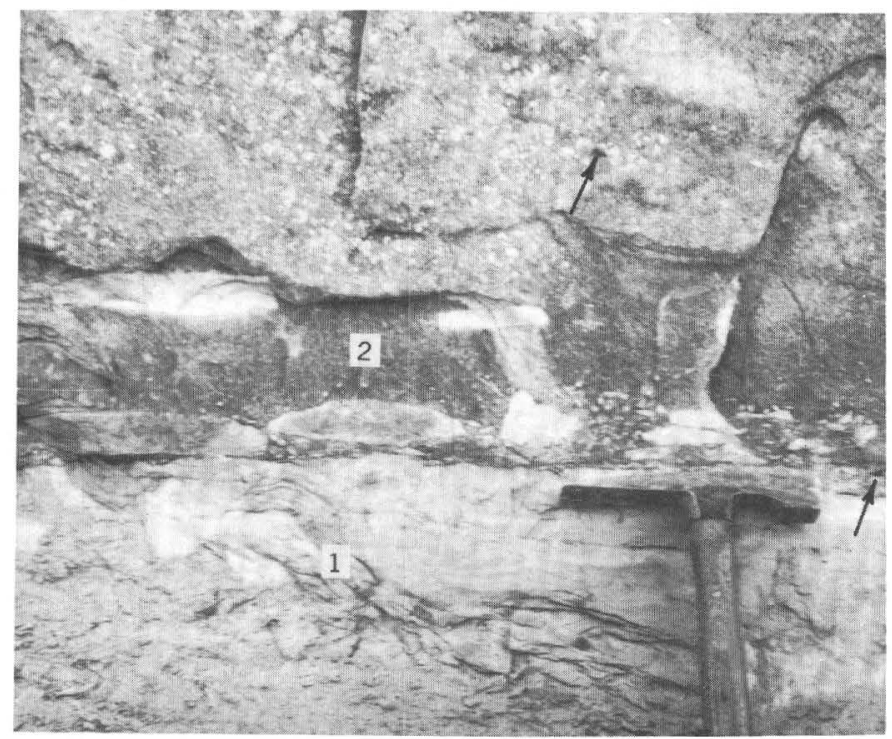

Figure 16.-Erosion surface between the Sips Creek Member of the Jelm Formation (1) and Canyon Springs Sandstone Member of the Sundance Formation (2) near Freezeout Mountains, southwest, about 0.6 mile west of locality shown in figure 9. Black or dark-gray chert pebbles (arrows) occur above the erosion surface everywhere, but reworked pieces of underlying rocks are uncommon. See also figures 15 (lower photograph ), 17, 18, and 19.

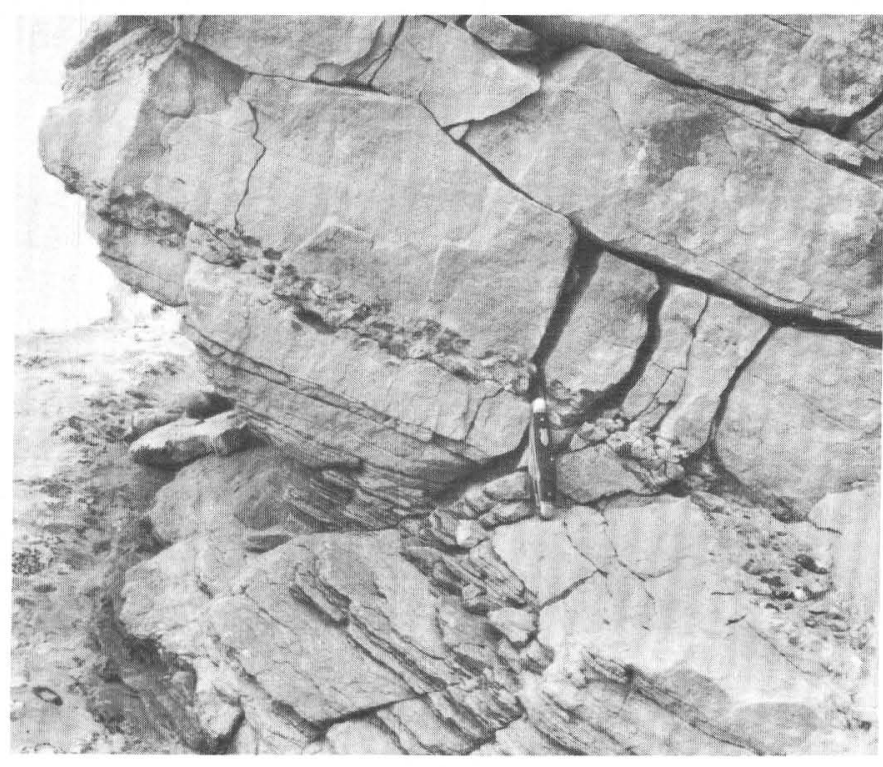

Figure 17.-Chert pebbles at the base of the Canyon Springs Sandstone Member of the Sundance Formation at Ferris, west (loc. 31, fig. 1). Underlying beds may be in wedge edge of transition zone of Nugget Sandstone (fig. 2). View toward south; knife is $3 \frac{1}{2}$ inches long.

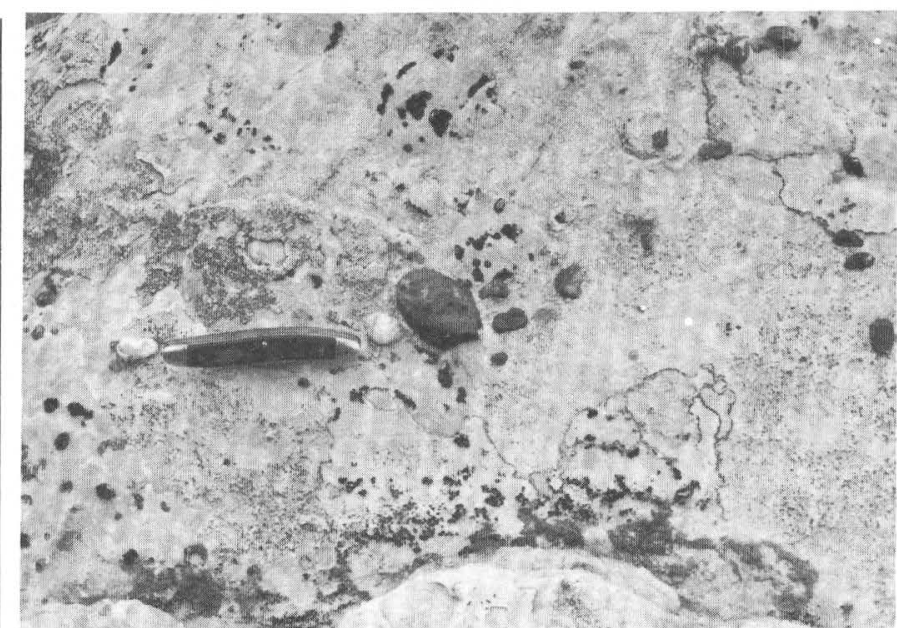

Figure 18.-Chert pebbles stuck to uppermost surface of the Bell Springs Member of the Nugget Sandstone. Overlying Canyon Springs Sandstone Member of the Sundance Formation has been stripped by erosion. Photograph taken about 100 feet north of locality shown in figure 17. Black chert pebble is about $21 / 4$ inches long.

sum Spring Formation. At this locality the lower part of the unit consists of oolitic thin-bedded ripple-marked sandstone, 4 feet thick, overlain by abundantly oolitic limestone and sandstone and a few shale partings, about 10 feet thick (fig. 19). About 500 feet northwest of this locality, the lower part of the flat-bedded sandstone unit is a solid bed of oolitic limestone 13 feet thick; the sandstone grades laterally into limestone. At Derby dome and Johnson Ranch, remnants of oolitic calcareous sandstone and oolitic limestone occur at the base of the Stockade Beaver Shale Member but are too thin to show in figure 2 (locs. 7, 8), and at Lander and at Dallas anticline (locs. 5, 6) no trace of the Canyon Springs was found. Oolitic limestone reappears at the base of the Stockade Beaver northwest of Lander and probably is continuous in the subsurface with the Canyon Springs of this report area (Imlay, 1953, table 2; fig. 7, this report).

\section{STOCKADE BEAVER SHALE AND HULETT SANDSTONE MEMBERS}

These names are used here as defined by Imlay (1947) in the Black Hills. The Stockade Beaver is present only in the northern half of the region shown in figure 1 , and there ranges in thickness from 110 feet at locality 18 to 12 feet at locality 6 and averages about 50 feet. The members consists mostly of greenish-gray shale and siltstone. In the southern half of the region, the Stockade Beaver is replaced by the Canyon Springs. 


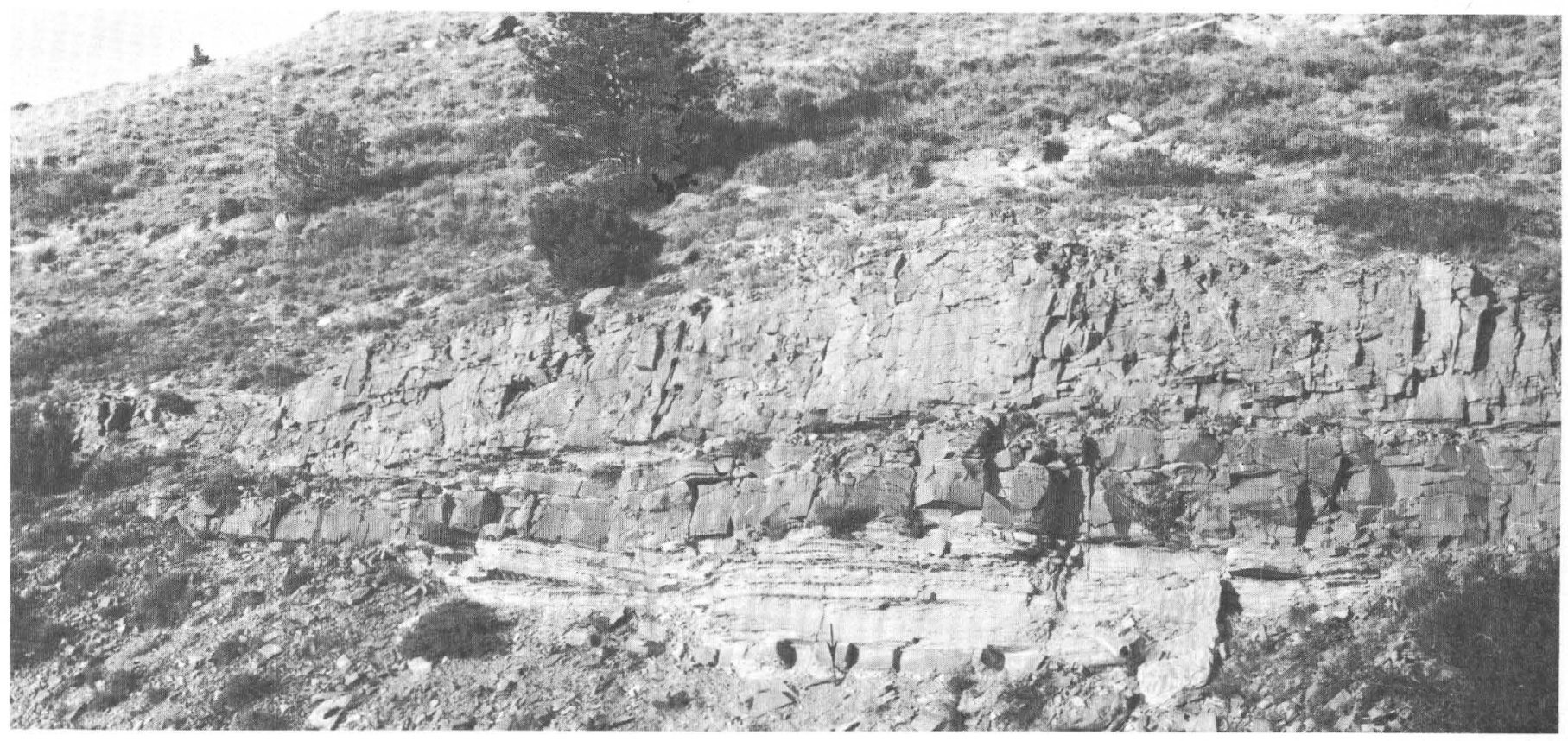

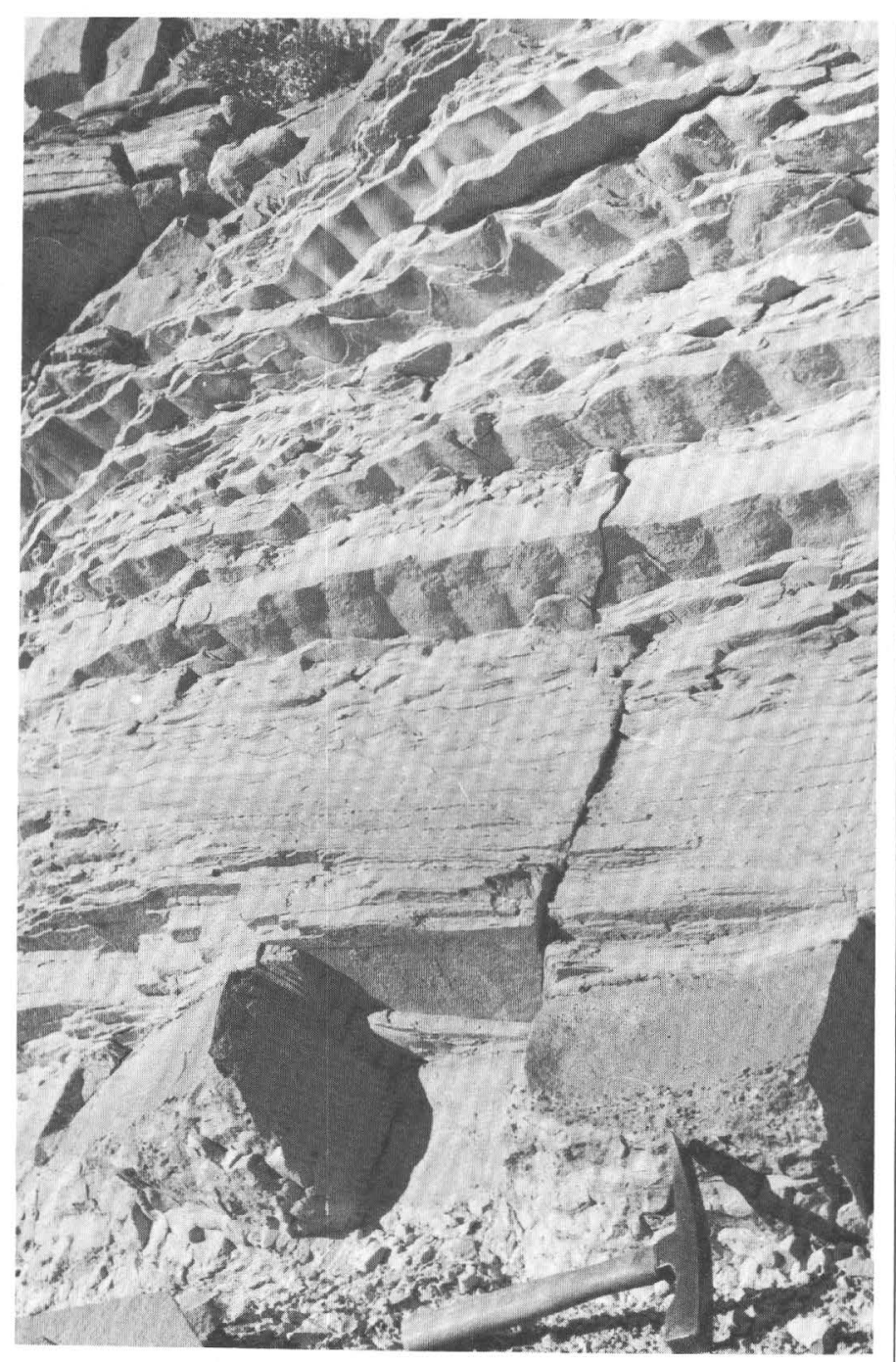

Figure 19.-Canyon Springs Sandstone Member of the Sundance Formation at Sheep Mountain (loc. 9, fig. 1). Lower part of member is sparsely oolitic sandstone with a zone of chert pebbles at the base; upper part is abundantly oolitic limestone and sandstone. Arrow in upper photograph points to hammer at base of unit. Photograph on the left is a closeup of the chert pebbles (at hammer point) at the contact of the Canyon Springs with the underlying Gypsum Spring Formation. Current ripple marks are common in the Canyon Springs but are generally less conspicuous than those shown here.

The Hulett, which is present everywhere except along the southern border of the area, consists of about equal parts of 'sandstone and shale. The sandstone beds characteristically make prominent ledges, and the top of the member commonly is marked by a pronounced break in the slope of the hillside on which it crops out. The member grades downward into the Stockade Beaver. The Hulett ranges in thickness from about 40 feet at locality 10 ito about 4 feet at locality 56 and averages about 18 feet.

\section{LAK MEMBER}

The Lak Member is used as defined by Imlay (1947) and consists of reddish-brown siltstone, sandy siltstone, and silty sandstone. It ranges in thickness from about 70 feet at locality 18 to about 7 feet at locality 51 (fig. $5)$ and averages about 40 feet. The member is present throughout the region; it is gray white to yellow white, rather than reddish brown, in the southern and southeastern parts of the area (locs. 51 and 58). The lower contact is gradational through 1-2 feet into the Hulett and locally is marked by gypsum nodules. The Lak Member characteristically makes smooth slopes covered 
by soil. Locally the uppermost and lowermost beds are bleached greenish or yellowish white. At Sheep Creek anticline, about 2.5 miles west of locality 30 , and at locality 15 , red beds in the Lak are intercalated with grayish-green shale, siltstone, and sandstone beds similar to those in overlying and underlying members of the Sundance. This suggests local intertonguing with the adjacent members.

\section{PINE BUTTE MEMBER}

The Pine Butte Member of the Sundance is well exposed at Flat Top anticline, west, its type section (loc. 51 , figs. $1,5,20$, and 21 ), about $1 \frac{1}{2}$ miles southwest of Pine Butte, for which the member is here named. The member was previously described and illustrated at the type section as member B of the Sundance Formation (Pipiringos, 1957, p. 22, 39-49, pl. 5). The Pine Butte Member is equivalent to about the lower 30 feet of the Redwater Shale Member as defined near Spearfish, S. Dak. (fig. 8), and at other places in the Black Hills by Imlay (1947).

The Pine Butte Member consists principally of greenish-white firmly lime cemented sandstone beds with intercalated siltstone and grayish-green to olive-green papery-fissile clay shale. Glauconite is locally conspicuous in the sandstone and siltstone beds. The sandstone beds make thin slabby ripple-marked ledges; many of the bedding surfaces are marked by raised centrally furrowed fossilized trails made by crawling organisms. These trails are an especially important characteristic in recognizing the member, inasmuch as they are absent from the overlying Redwater Shale Member of the Sundance. The Pine Butte locally intertongues with, or grades downward into, the underlying Lak Member.

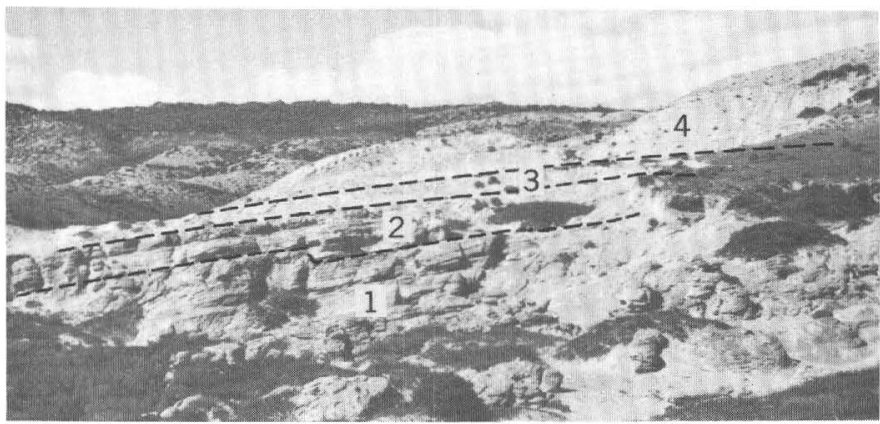

Figure 20.-Pine Butte Member of the Sundance Formation and underlying units at the type section (loc. 51, fig. 1). (1) Massive and (2) flat-bedded units of the Canyon Springs Sandstone; (3) Lak, and (4) Pine Butte Members of the Sundance Formation.

\section{REDWATER SHALE MEMBER}

The Redwater Shale Member as restricted here consists of clayey siltstone, clay shale, and firmly lime cemented beds of coquinoid sandstone or sandy coquinoid limestone. In the central part of the area, the member comprises, from bottom to top, a lower siltstone unit, a lower shale unit, an upper siltstone unit, and an upper shale unit (fig. 3). All units make slopes except the upper siltstone unit, which makes ledges. The upper two units intertongue with, and grade northwestward into, glauconitic coquinoid sandstone and coquinoid limestone that form cliffs, and the lower two units grade laterally northwestward into silty clayey sandstone that forms slopes. Both siltstone units contain coquinoid sandstone and coquinoid limestone beds, and these are especially conspicuous in the upper siltstone unit. Both shale units, by contrast, nowhere contain coquinoid sandstone or coquinoid limestone beds. The siltstone units contain no limestone concretions, but both shale units everywhere contain limestone concretions.

The basal bed of the Redwater Shale Member lies sharply on the underyling rocks on a surface of regional disconformity, and it nearly every where consists of nonfissile clayey siltstone or silty claystone in which belemnites are abundant. Belemnites are absent from underlying parts of the Sundance. Commonly, some of the belemnites at the contact are waterworn, and others are closely packed and have been alined parallel to each other by currents.

The Redwater Shale Member locally truncates the Pine Butte Member, as at localities 5-9, and belemnitebearing siltstone of the Redwater lies sharply on the Lak Member of the Sundance.

\section{WINDY HILL SANDSTONE MEMBER}

The Windy Hill Sandstone Member named herein is well exposed throughout much of its outcrop area in the east half of Wyoming, and particularly at Freezeout Mountains, east (loc. 44), which was chosen as the type section (fig. 22). The name comes from Windy Hill, about 4 miles west of the type section. The Windy Hill at the type section was described and illustrated as member $\mathbf{A}$ of the Sundance Formation by Pipiringos (1948a, p. 132-138; 1953, p. 34; 1957, p. 24-25, 39, pl. 5).

The Windy Hill Sandstone Member consists principally of ledge-forming sandstone beds. In central and southern Wyoming the sandstone is very fine to fine grained, limy, oolitic, and sparsely fossiliferous, and it weathers grayish white to brownish gray. In southeastern Wyoming the sandstone is fine to coarse grained, calcite cemented, sparsely oolitic, and rarely fossiliferous; it locally contains gray-green to dark-gray shale partings; and it weathers pale yellowish orange, tan, buff, or light brown. Bedding planes of the sandstone almost invariably exhibit small current ripple marks, 


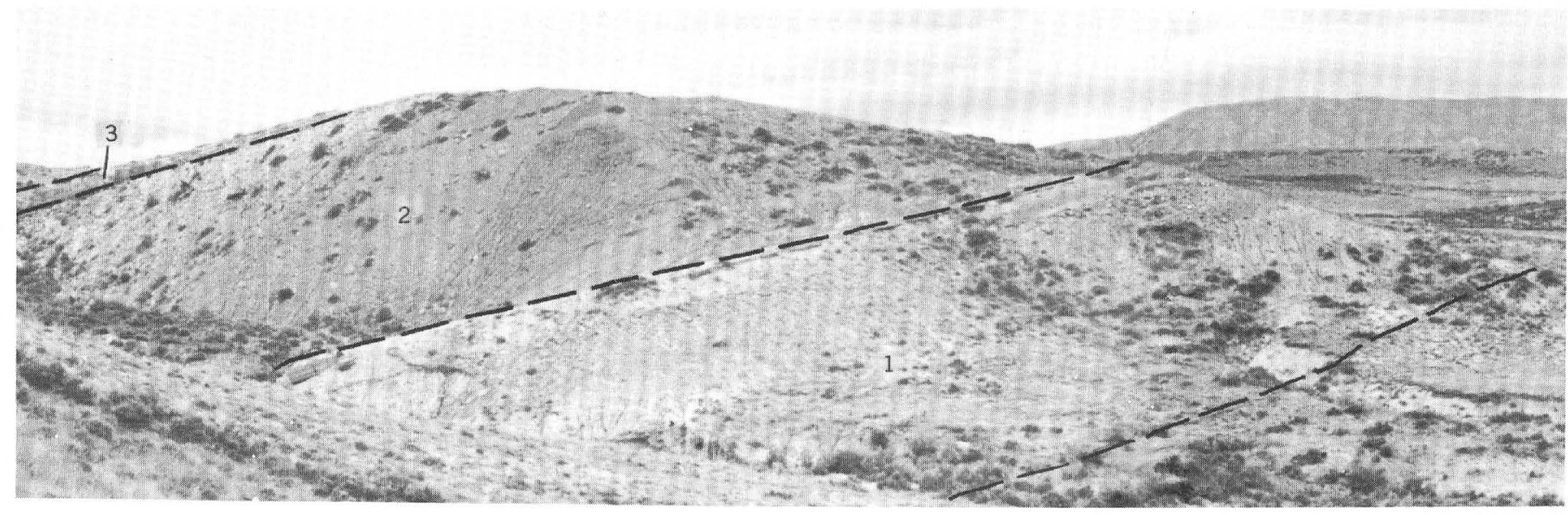

Figure 21.-Pine Butte Member of the Sundance Formation and overlying units. (1) Pine Butte, (2) Redwater Shale, and (3) Windy Hill Sandstone Members of the Sundance Formation. Base of Pine Butte concealed. View is about 200 feet to the right (west) of figure 20 .

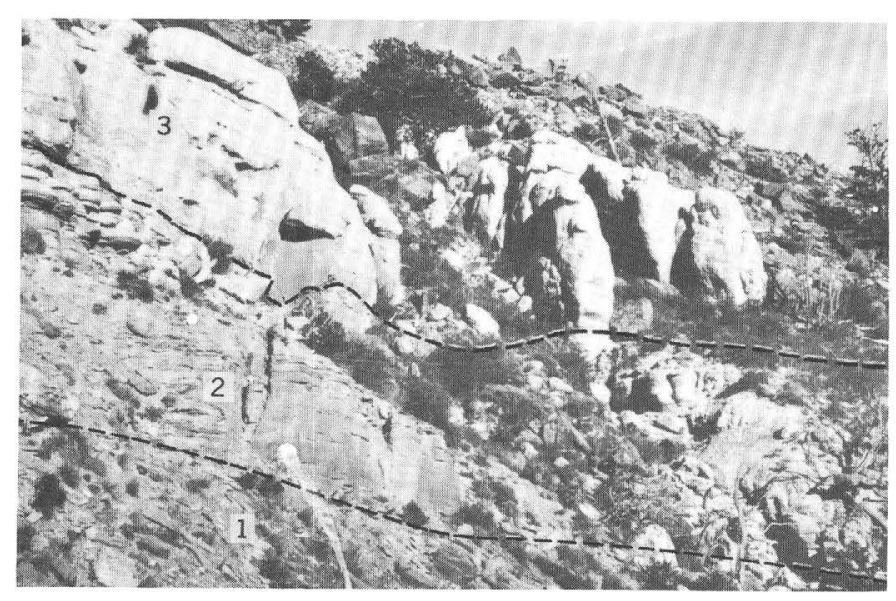

Frgure 22.-Windy Hill Sandstone Member of the Sundance Formation at the type section (loc. 44, fig. 1). (1) Redwater Shale and (2) Windy Hill Sandstone Members of the Sundance Formation; (3) lenticular sandstone at base of Morrison Formation.

some of which are of the interference type which has a reticulate pattern (fig. 23). The member is about 30 feet thick at the type section; it ranges from a maximum exposed thickness of about 57 feet at locality 34 to about 5 feet at locality 11 and a verages about 15 feet in the area shown in figure 1.

Regional detailed stratigraphic studies show that the Windy Hill Sandstone Member rests disconformably on the underlying Redwater Shale Member (Pipiringos, 1948a, b, 1953, 1957). Figure 3 illustrates the truncation of the upper shale and siltstone units of the Redwater between localities 35 and 44 . In the vicinity of Farthing, Wyo. (fig. 1), which is on the east side of the Laramie Mountains about 60 miles southeast of locality 51 , the lower shale and lower siltstone units of the Redwater are also truncated, and the Windy Hill Member rests directly on the Pine Butte Member. Similarly, the Windy Hill progressively truncates the Redwater Member from the Black Hills southward to Farthing, Wyo.

Local abrupt changes in thickness of the Windy Hill shown in figure 3 between localities 33 and 35 , and interfingering of the Windy Hill and the Morrision Formation observed by M. W. Reynolds (written commun., $1965)$ at the west end of the Ferris Mountains near locality 31 , suggest that the Windy Hill intertongues with the Morrision Formation in the area of this report just as it does along the Front Range as reported by Pipiringos (1957, p. 24; U.S. Geol. Survey, 1963).

A marine depositional environment for the Windy Hill is shown by the presence in it of oolites, oysters, Camptonectes, and belemnites (Pipiringos, 1957, p. 24). The base of the Windy Hill marks a disconformity of regional extent, but at most places the Windy Hill is too thin to map separately at conventional scales. Consequently, it is here regarded as a member of the marine Sundance Formation. A similar and undoubtedly correlative unit has been placed at the top of the Redwater Shale Member of the Sundance in the Black Hills by Robinson, Mapel, and Bergendahl (1964, p. 15-16). 

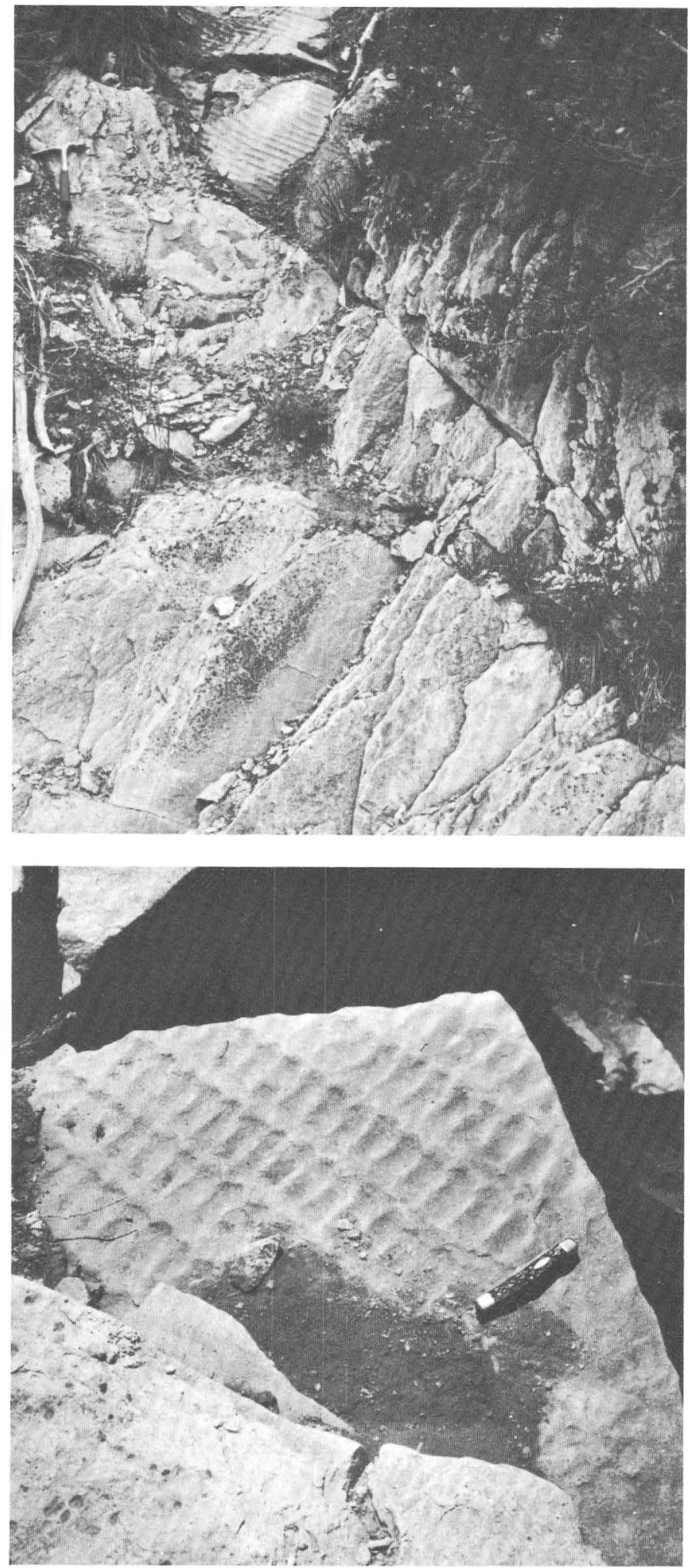

Figure 23.-Bedding features typical of the Windy Hill Sandstone Member of the Sundance Formation. Upper photograph shows current ripple marks and thin-bedded sandstone at Derby dome (loc. 7, fig. 1) ; lower photograph, interference ripple marks at Watkins Draw (loc. 40, fig. 1). Photographs by M. W. Reynolds.

\section{REFERENCES CITED}

Bartram, J. G., 1930, Triassic-Jurassic red beds of the Rocky Mountain region: Jour. Geology, v. 38, no. 4, p. 335-345.

- 1940, The stratigraphy and structure of eastern Wyoming and the Black Hills area, in Kansas Geol. Soc. Guidebook 14th Ann. Field Conf., Western South Dakota and eastern Wyoming, Aug. 26-Sept. 1, 1940: p. 113-119.

Bauer, C. M., 1934, Wind River Basin [Wyoming] : Geol. Soc. America Bull., v. 45, no. 4, p. 665-696.

Branson, E. B., and Branson, C. C., 1941, Geology of the Wind River Mountains, Wyoming: Am. Assoc. Petroleum Geologists Bull., v. 25, no. 1, p. 120-151.

Darton, N. H., 1899, Jurassic formations of the Black Hills of South Dakota: Geol. Soc. America Bull., v. 10, p. 383-396. - 1904, Comparison of the stratigraphy of the Black Hills, Bighorn Mountains, and Rocky Mountain front range: Geol. Soc. America Bull., v. 15, p. 379-448.

1908, Paleozoic and Mesozoic of central Wyoming: Geol. Soc. America Bull., v. 19, p. 403-470.

Dobbin, C. E., Bowen, C. F., and Hoots, H. W., 1929, Geology and coal and oil resources of the Hanna and Carbon Basins, Carbon County, Wyoming: U.S. Geol. Survey Bull. 804, $88 \mathrm{p}$.

Dobbin, C. E., Hoots, H. W., and Dane, C. H., 1928, Geology and oil and gas possibilities of the Bell Springs district, Carbon County, Wyoming: U.S. Geol. Survey Bull. 796-D, p. $171-197$.

Dobbin, C. E., and Reeside, J. B., Jr., 1927, Problems of the Chugwater-Sundance contact, a discussion: Am. Assoc. Petroleum Geologists Bull., v. 11, no. 11, p. 1235-1236.

Dresser, H. W., 1959, A field study of the Jurassic "Lower Sundance" beds in southeastern Wyoming: Wyoming Univ. Ph. D. thesis, $667 \mathrm{p}$.

High, L. R., Jr., and Picard, M. D., 1965, Sedimentary petrology and origin of analcime-rich Popo Agie Member, Chugwater ('Triassic) Formation, west-central Wyoming: Jour. Sed. Petrology, v. 35, no. 1, 49-70.

Hubbell, R. G., 1954, Stratigraphy of the Jelm, Nugget, and Sundance formation of northern Carbon County, Wyoming: Wyoming Univ. M.A. thesis, $131 \mathrm{p}$.

- 1956, Upper Triassic facies relations in northern Carbon County, Wyoming: Am. Assoc. Petroleum Geologists Bull., v. 40, no. 11, p. 2743-2748.

Imlay, R. W., 1945, Occurrence of Middle Jurassic rocks in the western interior of United States: Am. Assoc. Petroleum Geologists Bull., v. 29, No. 7, 1019-1027.

- 1947, Marine Jurassic of Black Hills area, South Dakota and Wyoming: Am. Assoc. Petroleum Geologists Bull., v. 31 , no. 2., p. 227-273.

1953, Western interior United States, pt. 1 of Callovian (Jurassic) ammonites from the United States and Alaska: U.S. Geol. Survey Prof. Paper 249-A, p. 1-39, 24 pls.

Keller, W. D., 1952, Analcime in the Popo Agie member of the Chugwater formation [Wyoming] : Jour. Sed. Petrology, v. 22 , no. 2 , p. $70-82$.

Kinney, D. M., 1955, Geology of the Unita River-Brush Creek area, Duchesne and Unitah Counties, Utah: U.S. Geol. Survey Bull. 1007, 185 p.

Knight, S. H., 1917, Age and origin of the red beds of southeastern Wyoming [abs.], with discussion by Erasmus Haworth and E. B. Branson: Geol. Soc. America Bull., v. 28, no. 1 , p. $168-169$. 
Kummel, Bernhard, 1954, Triassic stratigraphy of southeastern Idaho and adjacent areas: U.S. Geol. Survey Prof. Paper 254-H, p. 165-194.

Lee, W. T., 1927, Correlation of geologic formations between east-central Colorado, central Wyoming, and southern Montana: U.S. Geol. Survey Prof. Paper 149, 80 p.

Lee, W. T., Stone, R. W., Gale, H. S., and others, 1915, Guidebook of the western United States, pt. B., The Overland Route, with a side trip to Yellowstone Park: U.S. Geol. Survey Bull. 612, 244 p.

Love, J. D., 1939, Geology along the southern margin of the Absaroka Range, Wyoming: Geol. Soc. America Spec. Paper $20,134 \mathrm{p}$.

— 1957, Stratigraphy and correlation of Trassic rocks in central Wyoming, in Wyoming Geol. Assoc. Guidebook 12th Ann. Field Conf., Southwest Wind River Basin, 1957: p. 39-46.

— 1958, Stratigraphy and fossils of marine Jurassic rocks along the southern margin of the Powder River Basin, Wyoming, in Wyoming Geol. Assoc. Guidebook 13th Ann. Field Conf., Powder River Basin, 1958: p. 64-70.

Love, J. D., Denson, N. M., and Botinelly, Theodore, 1949, Geology of the Glendo area, Wyoming: U.S. Geol. Survey Oil and Gas Inv. Prelim. Map 92.

Love, J. D., Johnson, C. O., Nace, H. L., Sharkey, H. H. R., Thompson, R. M., Tourtelot, H. A., and Zapp, A. D., 1945, Stratigraphic sections and thickness maps of Triassic rocks in central Wyoming: U.S. Geol. Survey Oil and Gas Inv. Prelim, Chart 17.

Love, J. D., Tourtelot, H. A., Johnson, C. O., Sharkey, H. H. R., Thompson, R. M., and Zapp, A. D., 1945, Stratigraphic sections and thickness maps of Jurassic rocks in central Wyoming: U.S. Geol. Survey Oil and Gas Inv. Prelim. Chart 14.

Love, J. D., Tourtelot, H. A., Johnson, C. O., Thompson, R. M., Sharkey, H. H. R., and Zapp, A. D., 1947, Stratigraphic sections of Mesozoic rocks in central Wyoming: Wyoming Geol. Survey Bull., 38, 59 p.

Mapel, W. J., and Bergendahl, M. H., 1956, Gypsum Spring formation, northwestern Black Hills, Wyoming and South Dakota: Am. Assoc. Petroleum Geologists Bull., v. 40, no. 1, p. 84-93.

Murphy, J. F., and Richmond, G. M., 1965, Geologic map of the Bull Lake West Quadrangle, Fremont County, Wyo.: U.S. Geol. Survey Geol. Quad. Map GQ-432.

Neely, Joseph, 1937, Stratigraphy of the Sundance formation and related Jurassic rocks in Wyoming and their petroleum aspects: Am. Assoc. Petroleum Geologists Bull., v. 21, no. 6, p. 715-770.

Pipiringos, G. N., 1948a, Stratigraphy of the Sundance Formation, the Nugget(?) Sandstone, and the Jelm Formation (restricted), in Laramie Basin, Wyoming: Wyoming Univ. M.A. thesis, $143 \mathrm{p}$. 1948b, Marine Jurassic and related rocks of Laramie Basin, Wyoming [abs.] : Geol. Soc. America Bull., v. 59, no. 12, pt. 2, p. 1399-1400.

1953, Correlation of marine Jurassic and related rocks in the Laramie Basin, Wyoming in Wyoming Geol. Assoc. Guidebook 8th Ann. Field Conf., Laramie Basin and North Park, 1953 : p. 34-39.

1957, Stratigraphy of the Sundance, Nugget and Jelm Formations in the Laramie Basin, Wyoming: Wyoming Geol. Survey Bull. 47, 63 p.

Poole, F. G., and Stewart, J. H., 1964, Chinle Formation and Glen Canyon Sandstone in northeastern Utah and northwestern Colorado, in Geological Survey research 1964: U.S. Geol. Survey Prof. Paper 501-D, p. D30-D39.

Reeside, J. B., Jr., 1929, Triassic-Jurassic "Red Beds" of the Rocky Mountain Region-a discussion: Jour. Geology, v. 37, no. 1, p. 47-63.

Robinson, C. S., Mapel, W.J., and Bergendahl, M. H., 1964, Stratigraphy and structure of the northern and western flanks of the Black Hills uplift, Wyoming, Montana, and South Dakota: U.S. Geol. Survey Prof. Paper 404, 134 p.

Shaw, A. B., and McGrew, P. O., 1954, Correlation of the Mesozoic and Tertiary Formations of Wyoming, in Wyoming Geol. Assoc. Guidebook 9th Ann. Field Conf., Casper area, 1954: Correlation chart 1 , in pocket.

U.S. Geological Survey, 1962, Geological Survey research 1962 : U.S. Geol. Survey Prof. Paper 450-A, p. A35.

1963, Geological Survey research 1963 : U.S. Geol. Survey Prof. Paper 475-A, p. A86.

1964, Geological Survey research 1964 : U.S. Geol. Survey Prof. Paper 501-A, p. A95.

1965, Geological Survey research 1965 : U.S. Geol. Survey Prof. Paper 525-A, p. A88.

Williston, S. W., 1904, Notice of some new reptiles from the Upper Triassic of Wyoming: Jour. Geology, v. 12, no. 8, p. 688-697.

Wilmarth, V. R., and Smith, R. D., 1957, Preliminary geologic map of the west-central part of the Minnekahta quadrangle, Fall River County, South Dakota: U.S. Geol. Survey Mineral Inv. Field Studies Map MF-67.

Woodruff, E. G., 1911, The Lander oil field, Fremont County, [pt. 1] of The Lander and Salt Creek oil fields, Wyoming: U.S. Geol. Survey Bull. 452, p. 1-36.

Wroble, J. L., 1953, Correlation of the Sundance, Nugget and Popo Agie Formations in central Wyoming: Wyoming Univ. M.A. thesis, $151 \mathrm{p}$.

Wyoming Geological Association, 1946, Central and southeastern Wyoming, in Wyoming Geol. Assoc. Guidebook 1st Ann. Field Conf., Aug. 7-10, 1946: 56 p. 